\title{
San Pedro Springs Park Improvements Archaeological Testing and Monitoring at 41BX19, San Antonio, Bexar County, Texas
}

José E. Zapata

Center for Archeological Research, University of Texas at San Antonio

Barbara A. Meissner

Follow this and additional works at: https://scholarworks.sfasu.edu/ita

Part of the American Material Culture Commons, Archaeological Anthropology Commons, Environmental Studies Commons, Other American Studies Commons, Other Arts and Humanities Commons, Other History of Art, Architecture, and Archaeology Commons, and the United States History Commons

Tell us how this article helped you.

This Article is brought to you for free and open access by the Center for Regional Heritage Research at SFA ScholarWorks. It has been accepted for inclusion in Index of Texas Archaeology: Open Access Gray Literature from the Lone Star State by an authorized editor of SFA ScholarWorks. For more information, please contact cdsscholarworks@sfasu.edu. 
San Pedro Springs Park Improvements Archaeological Testing and Monitoring at 41BX19, San Antonio, Bexar County, Texas

\section{Creative Commons License}

\section{(c) (1) \&}

This work is licensed under a Creative Commons Attribution-NonCommercial 4.0 International License 


\section{San Pedro Springs Park Improvements}

A rchaeological Testing and M onitoring at
41BX19, San A ntonio, Bexar County, Texas

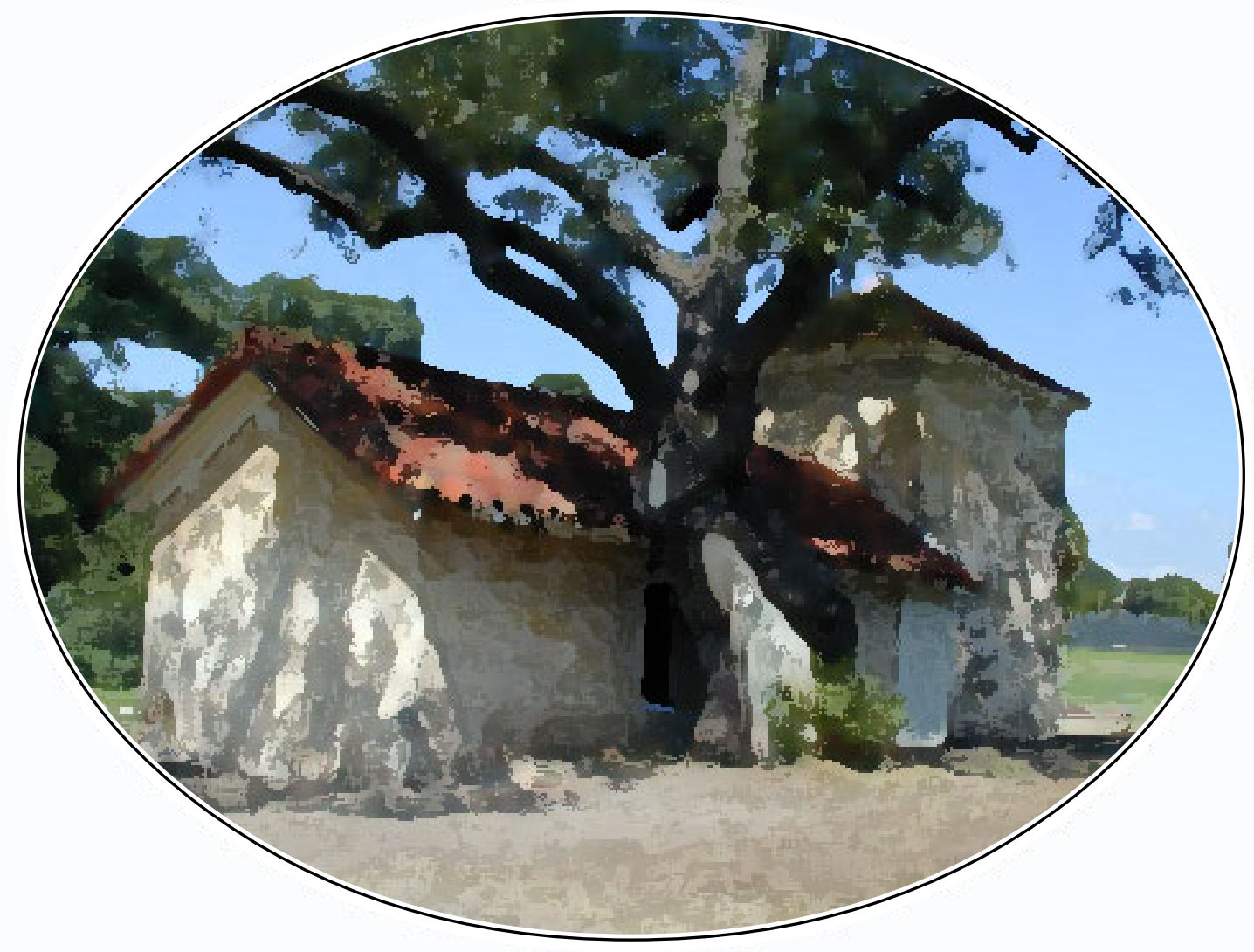

by

José E. Zapata and Barbara A. M eissner

Center for Archaeological Research The University of Texas at San Antonio Archaeological Survey Report, No. 331 2003
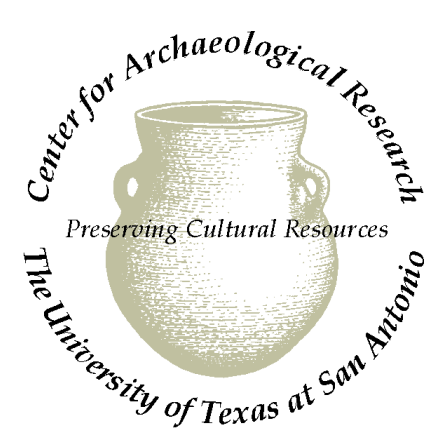


\title{
San Pedro Springs Park Improvements
}

\section{A rchaeological Testing and $M$ onitoring at 41BX 19, San A ntonio, Bexar County, Texas}

by

José E. Zapata and Barbara A. M eissner

\author{
Steve A . Tomka \\ Principal Investigator
}

Texas A ntiquities Permit N 0. 2776

Center for Archaeological Research

The University of Texas at San Antonio Archaeological Survey Report, No. 331

(C) copyright 2003 
The following information is provided in accordance with the General Rules of Practice and Procedure, Chapter 26.24 (Investigative Reports), Texas Antiquities Committee:

1. Type of investigation: Testing and Monitoring

2. Project name: San Pedro Springs Park Testing/Monitoring (41BX19)

3. County: Bexar

4. Principal investigator: Steve A. Tomka

5. Name and location of sponsoring agency: City of San Antonio, Department of Parks and Recreation, P.O. Box 389966, 506 Dolorosa, San Antonio, Texas, 78283-3966

6. Texas Antiquities Permit No.: 2776

7. Published by the Center for Archaeological Research, The University of Texas at San Antonio, 6900 N. Loop 1604 W., San Antonio, Texas 78249-0658, 2003

A list of publications offered by the Center for Archaeological Research is available. Call (210) 458-4378; write to the Center for Archaeological Research, The University of Texas at San Antonio, 6900 N. Loop 1604 W., San Antonio, Texas 78249-0658; e-mail to car@lonestar.utsa.edu; or visit CAR's web site at http://car.utsa.edu. 


\section{A bstract:}

The archaeological testing and monitoring reported here was conducted within the boundaries of San Pedro Springs Park, San Antonio, Bexar County, Texas, between January and October 2002. The park is listed in the National Register of Historic Places (41BX19) and contains significant prehistoric and historic archaeological resources. This investigation was conducted under Texas Antiquities Permit No. 2776 and was performed for the City of San Antonio Parks and Recreation Department. This report presents the results of archaeological testing and monitoring of areas to be impacted by park improvements. The improvements included the restoration and landscaping of a mid-nineteenthcentury structure; construction of a new playground; modifications to an existing playground; planting of trees; and the installation of a sprinkler system. This work resulted in the verification of a mid-nineteenth-century date for the Block House and the identification of the location of two historic trash deposits and a burned rock concentration. 


\section{Table of Contents:}

Abstract

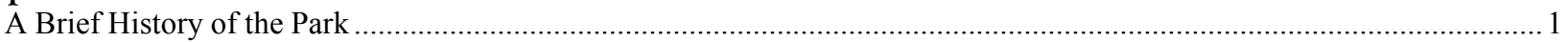

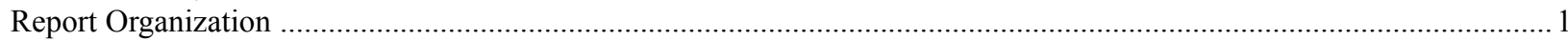

Chapter 2: Previous Investigations

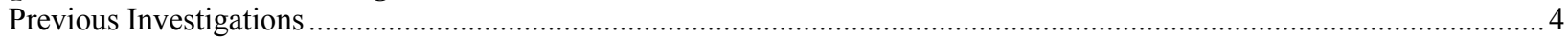

\section{Chapter 3: Scope of Work and Methods}

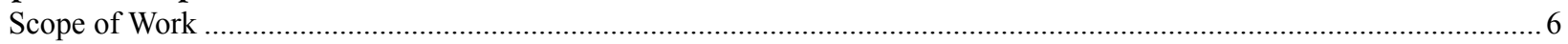

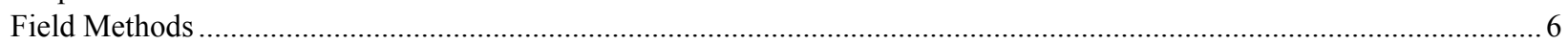

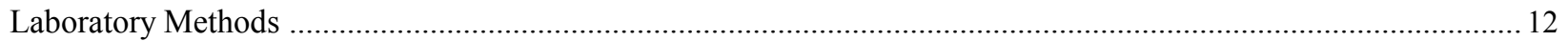

Chapter 4: Results of Investigations

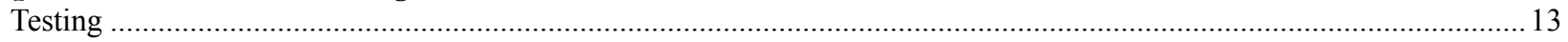

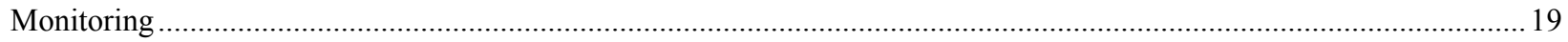

Chapter 5: The Artifacts

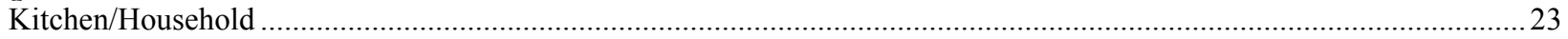

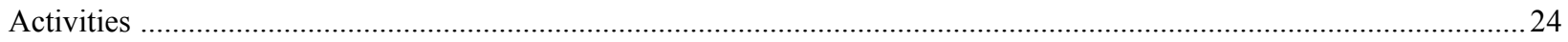

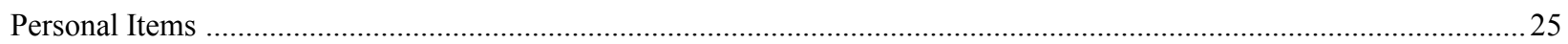

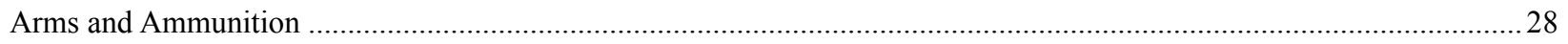

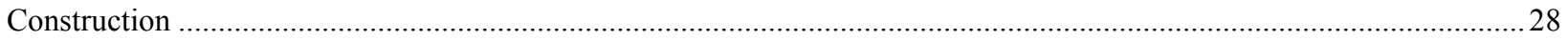

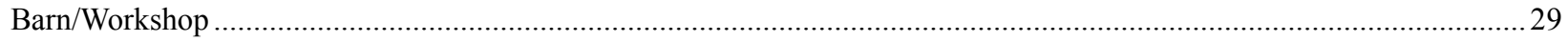

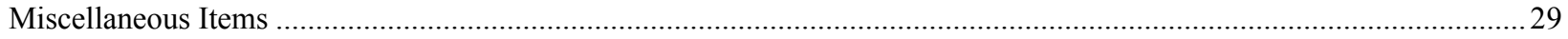

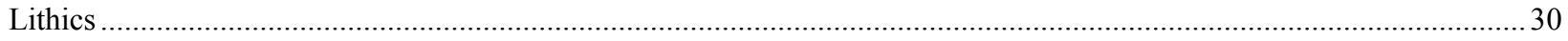

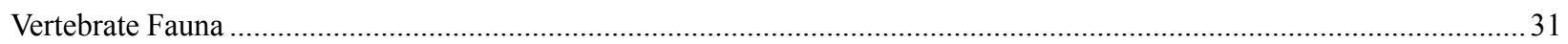

Chapter 6: Summary and Recommendations

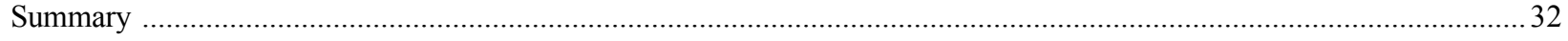

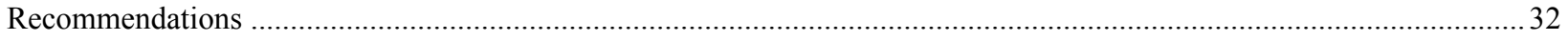

References Cited

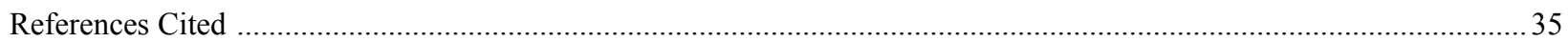




\section{Figures:}

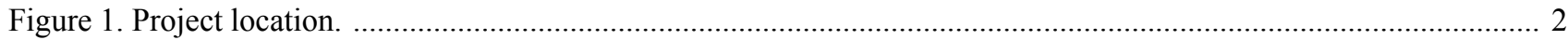

Figure 2. The Block House in 2002, during renovation. ......................................................................................... 3

Figure 3. Location of previous investigations in the park and known regions of archaeological sensitivity. ...................... 5

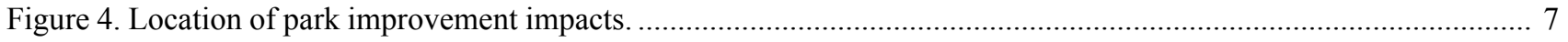

Figure 5. Placement of shovel tests and test units in Area 1- Block House. .................................................................. 8

Figure 6. Locations of shovel tests in Area 2 - New Playground. ............................................................................ 9

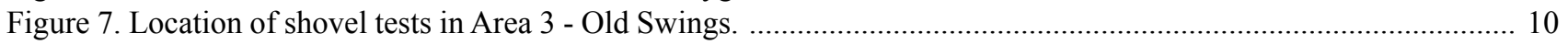

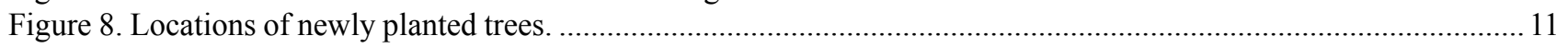

Figure 9. U2002-01 at $30 \mathrm{~cm}$, showing large tree root piercing the foundation. .................................................... 15

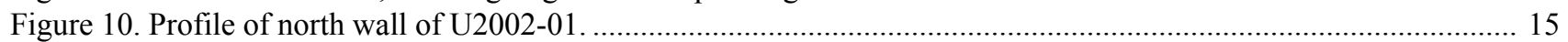

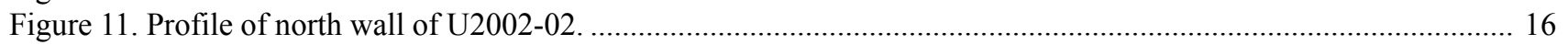

Figure 12. Results of monitoring trenches for sprinkler system lines. ...................................................................... 21

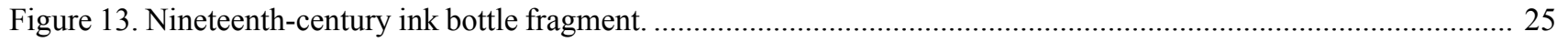

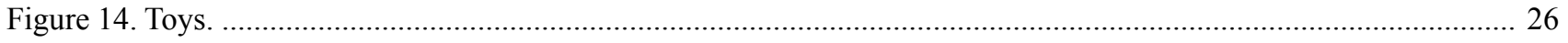

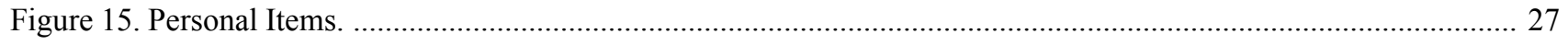

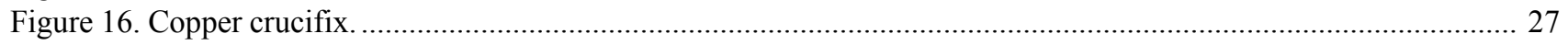

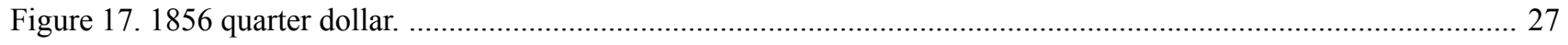

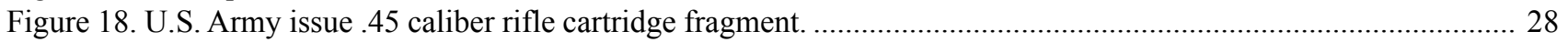

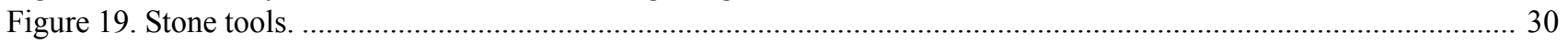

Figure 20. Impact zones within San Pedro Springs Park. ....................................................................................... 33 


\section{Tables:}

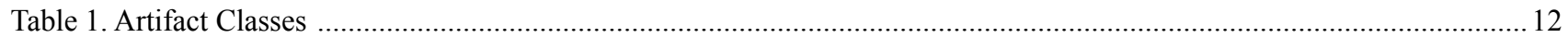

Table 2. Summary of Artifacts Recovered from Area 1 - Block House …................................................................ 14

Table 3. Summary of Artifacts Recovered from Area 2 - New Playground ….................................................................. 17

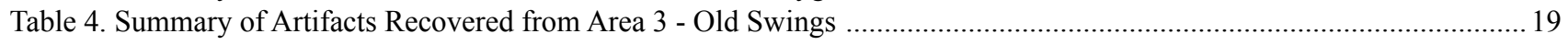

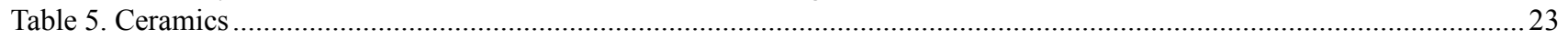

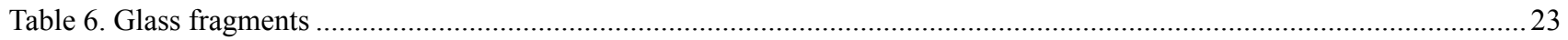

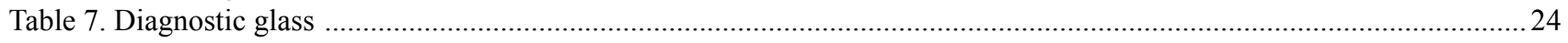

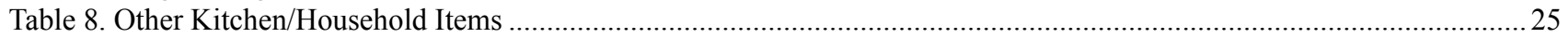

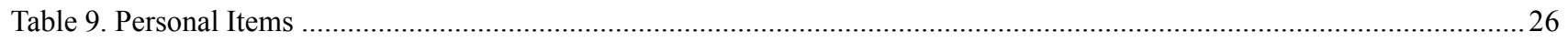

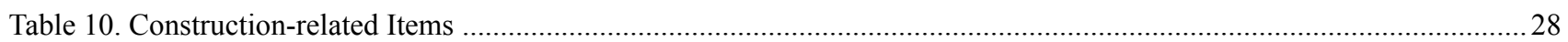

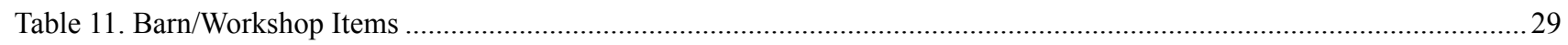

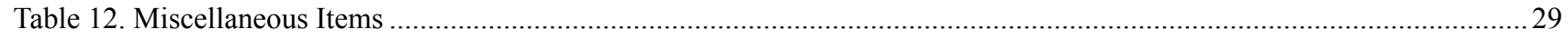

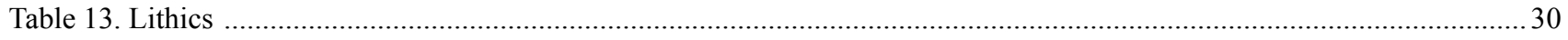

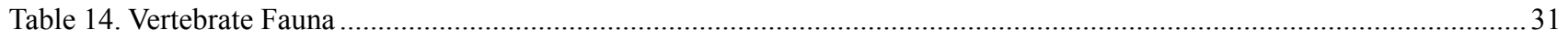

Table 15. Recommendations for Various Levels of Impact within Identified Zones ..............................................................34 


\section{A cknowledgments:}

The authors wish to acknowledge the cooperation and assistance of numerous citizens and public servants involved in this project. Thanks are due Hector Cardenas of the Friends of San Pedro Springs Park and Wayne Price of the Holloman/Price Foundation. For their technical and logistical support, thanks are also due Rodney Dziuk and Scott Stover of the City of San Antonio Parks and Recreation Department. We'd also like to thank all the contractors and their employees who worked with us on this project, for their cooperation.

Steve A. Tomka, Director of the Center for Archaeological Research, was the Principal Investigator, and also provided advice on the analysis of the lithics. José E. Zapata was the Project Archaeologist for this project. In the field, he was assisted by Antonia Figueroa, Brian Langner, Barbara A. Meissner, Rick C. Robinson, and Kristi Miller Ulrich. Anne A. Fox provided advice on the analysis of the ceramics. Barbara A. Meissner co-authored and edited the final report.

The authors would especially like to express appreciation for the assistance provided by the administrative staff at the Center for Archaeological Research-Sherri Suñaz and Tammy Hosek, and their assistants. Drafting was completed by Richard Young and Bruce Moses. Our technical editor was Johanna Hunziker. 



\section{Chapter 1:}

This archaeological project was undertaken in response to planned park improvements that impact several areas of San Pedro Springs Park, on the northern side of downtown San Antonio, Bexar County, Texas. This investigation was carried out on behalf of the City of San Antonio, Parks and Recreation Department, and was performed by staff archaeologists from the Center for Archaeological Research (CAR) at the University of Texas at San Antonio. The project was conducted under Texas Antiquities Permit No. 2776, in compliance with the Antiquities Code of Texas (Title 9, Chapter 191 of the Texas Natural Resources Code of 1977, as amended), its attendant Rules of Practice and Procedure (Texas Administrative Code, Title 13, Part II, Chapter 26), and the Council of Texas Archeologists Guidelines.

San Pedro Springs Park (41BX19) is a significant prehistoric and historic property. It is listed on the National Register of Historic Places (NRHP) and is a State Archeological Landmark (SAL). The park covers 46 acres, and is bounded by San Pedro Avenue, West Ashby Place, North Flores and Myrtle streets (Figure 1). Previous work has identified a significant prehistoric component, a small portion of the San Pedro Acequia that dates to ca. 1776-1778, and a section of the Alazán Acequia that dates to ca. 1875-1876. The park features at least 11 major springs and numerous minor springs (Brune 1981:73). The largest of the springs is considered the head of San Pedro Creek. Numerous prehistoric, Spanish Colonial, and more recent historic artifacts have been recovered in the park (Houk 1999; Meissner 2000). A reconstructed section of a nineteenthcentury acequia channel (Fox 1978, 1979:11; Nickels and Cox 1996) and a mid-nineteenth-century structure, known as the Block House (also known as the "Old Fort" [Figure $2]$ ), are the only two obvious historic features. The park is said to hold Paleoindian deposits (Meissner 2000:39; Orchard and Campbell 1954), although modern archaeological surveys have not located these.

\section{A Brief $\mathrm{H}$ istory of the Park}

A detailed history of the park is available in Meissner (2000; see also Kendall 2002; San Antonio Parks and Recreation Department 2002). The following is a very brief summary.
The waters of San Pedro Springs have drawn people to this location for at least 11,000 years (Black 1989; Orchard and Campbell 1954). When the Spanish expeditions arrived in the valley of the San Antonio River they found the plentiful water an important factor in their decision to establish and locate the new mission of San Antonio de Valero and Presidio San Antonio de Béxar near San Pedro Springs. Though both of these institutions were later moved, the springs continued to supply water for part of the acequia system that was developed in the Colonial period (Cox 2000). By 1731, what is now San Pedro Springs Park was established as public land for the purpose of channeling water from San Pedro Springs and creating irrigable ejidos (parcels).

The City of San Antonio maintains that this is the second oldest park in the United States (San Antonio Parks and Recreation Department 2002). In 1852, the San Antonio city council designated "San Pedro Springs Reserve" a public park. The boundaries of this tract of land have remained unchanged since that time.

Throughout the nineteenth century, the park went through extensive modifications associated with landscaping, artificial lake construction (see Houk 1999:14), erection of several structures (including the Block House), recreational facilities (including a zoo), and excavation of the Alazán Acequia (Cox 2000:12-15). In the twentieth century, a public library and playhouse, as well as a softball complex, have been constructed in the park. Extensive landscape changes, and road and walkway improvements have continued throughout the twentieth century and into the twenty-first (Houk 1999; Meissner 2000).

\section{Report O rganization}

The second chapter of this report summarizes the results of previous investigations. The findings presented in Chapter 2 were used to guide the scope and methods of the current project, as described in Chapter 3. Chapter 4 details the results of the work performed, and is presented under two major headings: Testing and Monitoring. A description of the recovered artifacts is presented in Chapter 5. Conclusions and recommendations are presented in Chapter 6. A complete provenienced artifact list is available upon request from CAR. 


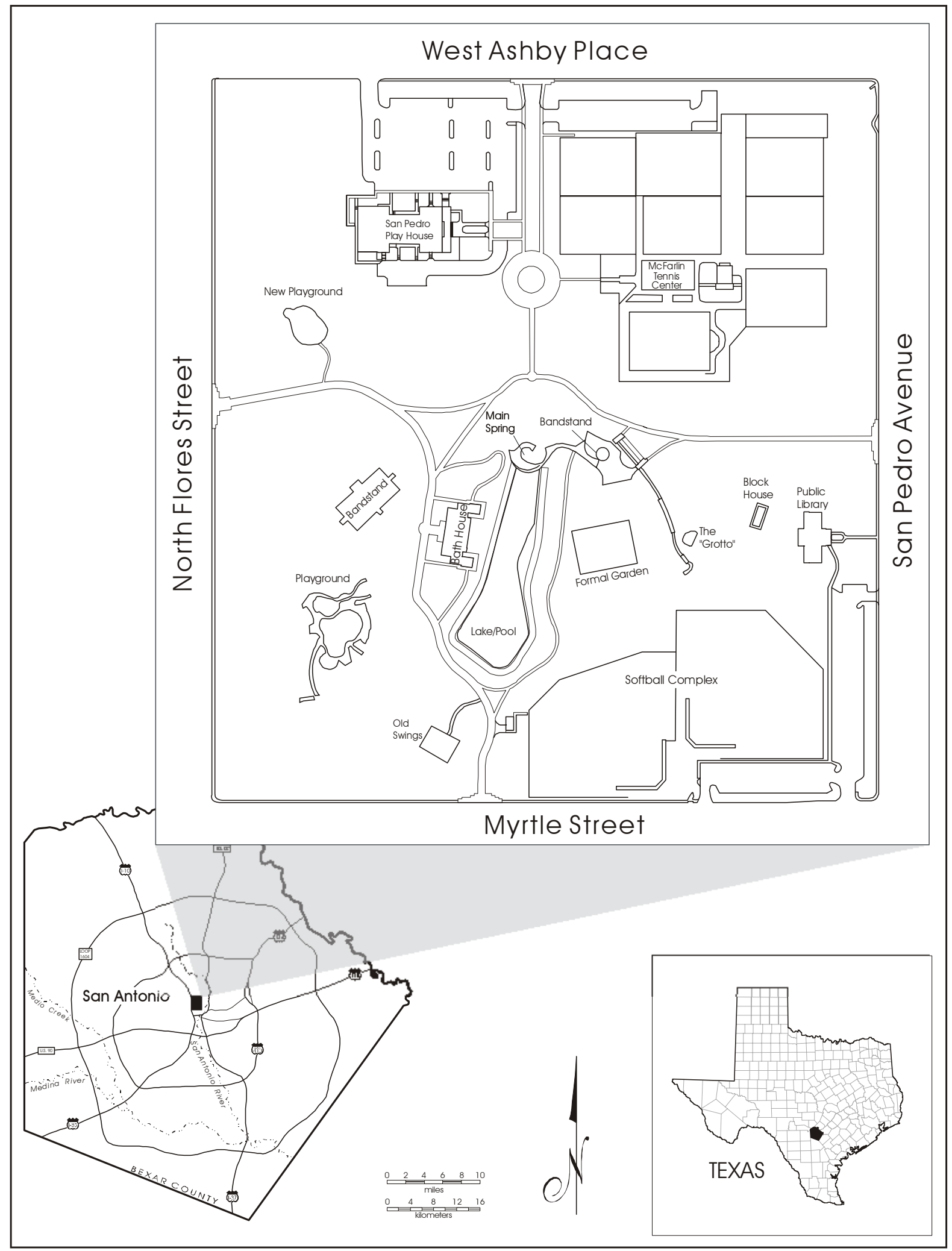

Figure 1. Project location. 


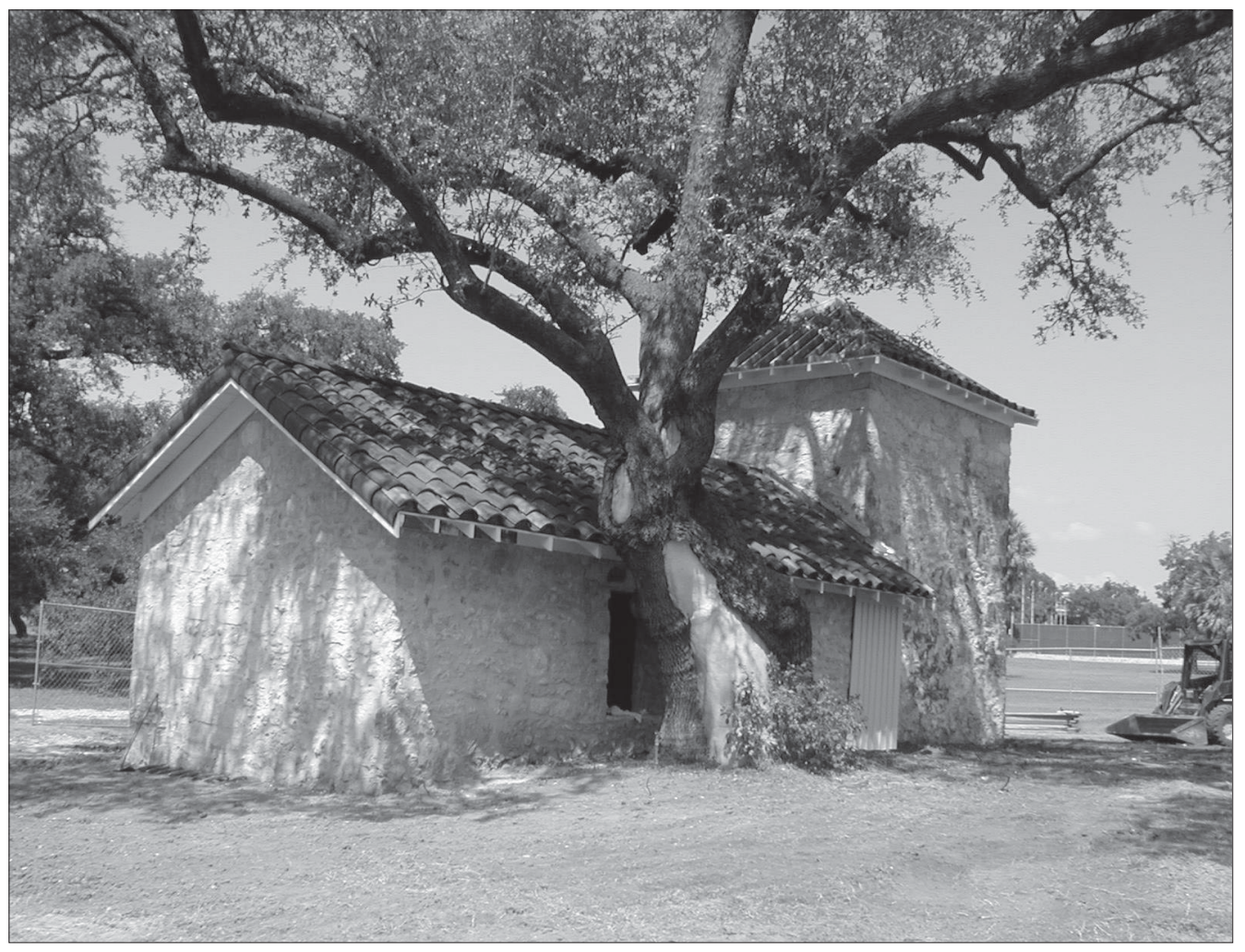

Figure 2. The Block House in 2002, during renovation. 


\section{Chapter 2: $\quad$ Previous Investigations}

The first professional archaeological investigation of the grounds of San Pedro Springs Park took place in 1977, during reconstruction of a section of the Alazán Acequia. At that time, Fox (1978) recorded a two-phase construction sequence in the acequia.

It was not until 20 years later that more archaeological work was done in the park. Between 1996 and 1999, in a series of projects, CAR investigated more of the park (Figure 3). In 1996, Meissner (2000) found a thin scatter of prehistoric and historic artifacts in most of a series of 38 shovel tests along the western edge of the park, and extremely dense deposits of prehistoric artifacts in some shovel tests along the southwestern edge of the park (Region 1 in Figure 3). The Alazán Acequia channel was recorded in a backhoe trench in the northwestern part of the park, and it was noted that the acequia had been dug a meter into the limestone bedrock (Meissner 2000:23-24).

In 1998, as a result of a pedestrian survey, shovel testing, and backhoe trenching, Houk (1999:24) identified six culturally sensitive areas. By combining the information gathered in Houk (1999), Meissner (2000), and a series of old maps, Figure 3 defines a series of regions of archaeological sensitivity based on known prehistoric or historic deposits or features.

Region 1, identified in 1996 (Meissner 2000:28-29), was damaged by construction activities (see Meissner 2000:3) and was intensively tested in 1998 (Houk et al. 2000). It was noted that this area is extremely sensitive and should not be disturbed.

A burned rock feature (Region 2 in Figure 3) was initially identified during a pedestrian survey, and verified by means of shovel testing (Houk 1999:24). The majority of the burned rock feature is buried about $20 \mathrm{~cm}$ ( 8 in.) below surface.

Prehistoric deposits were also encountered by means of shovel testing at $20 \mathrm{~cm}$ (8 in.) below surface in Region 3 (Figure 3). Additional prehistoric deposits were encountered in Region 4 at $30 \mathrm{~cm}$ (12 in.) below surface. Both prehistoric and historic artifacts were located on the surface in Region 5 (Houk 1999:14).
Region 6 is an area with potential historic features, extending from the footprint of the service building in the south-central part of the park to the southern edge of the new lake/pool (Figure 3). This is the probable location of the Colonialperiod dam and the beginning of the San Pedro Acequia. Although backhoe trenching failed to locate significant deposits or features in Region 6, it was proposed that disturbance in this area be kept to a minimum and permitted only in the presence of a qualified archaeologist.

Other historic features highlighted in Figure 3 are Region 7 -the footprint of the Alazán Acequia, including the reconstructed section and the area around San Pedro Spring (main spring)- and the area immediately adjacent the ca. 1850 Block House, Region 8.

In addition to the information summarized here and in Figure 3 , Meissner (2000:83-87) noted that large areas of the park had not yet been tested and their archaeological importance was unknown. 


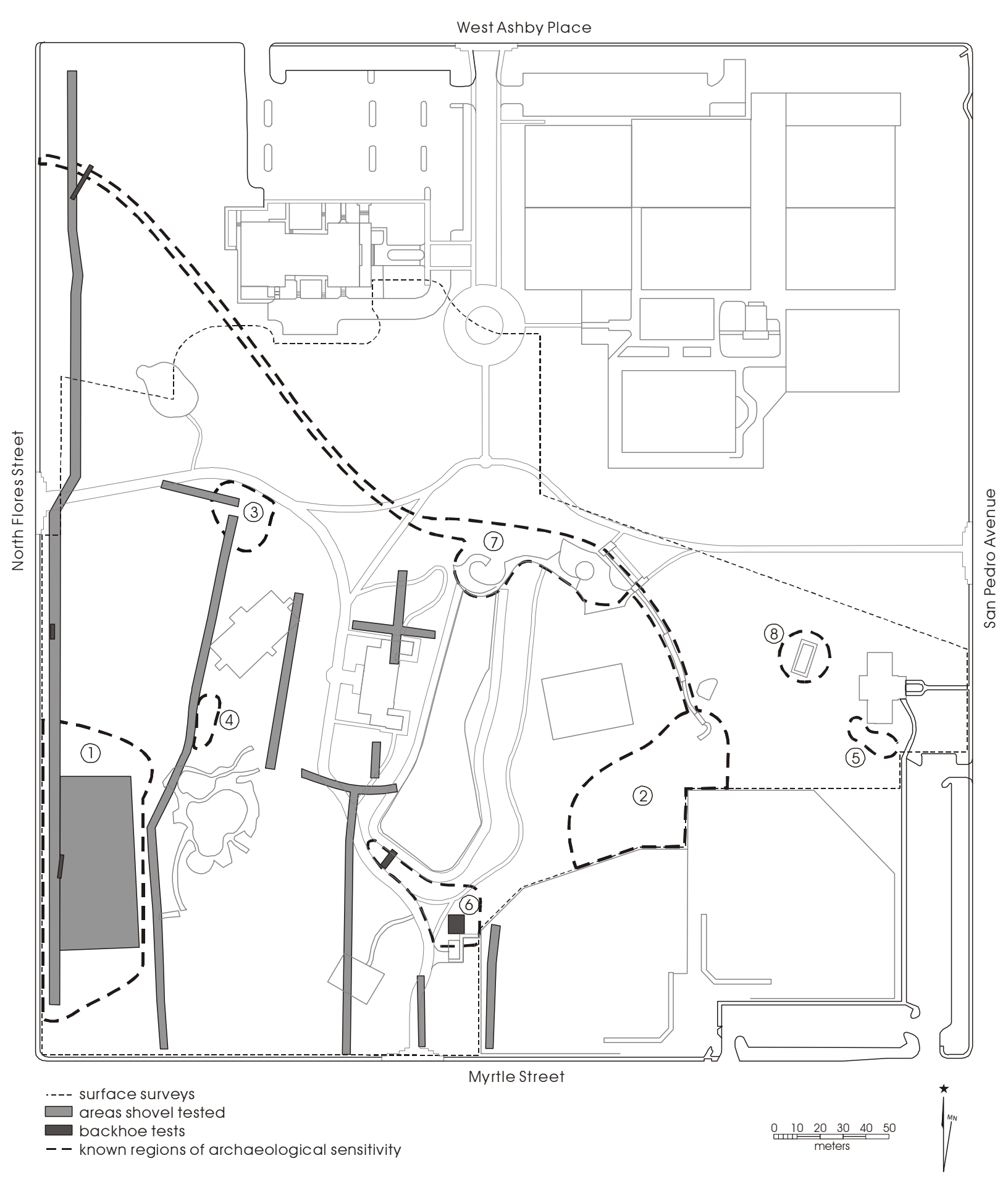

Figure 3. Location of previous investigations in the park and known regions of archaeological sensitivity (based on Houk 1999:24 and Meissner 2000:84-87). 


\section{Chapter 3: $\quad$ Scope of W ork and M ethods}

\section{Scope of W ork}

This archaeological project was undertaken in response to several proposed park improvements that were to impact three areas of the park (Figure 4). For ease of discussion, these areas are referred to as Areas 1,2, and 3. Area 1 is the area immediately around the structure known as the Block House (see Figure 2). Areas 2 and 3 (see Figure 4) are adjacent to known locations of sensitive archaeological deposits, but their potential to contain additional subsurface resources was not known at the time fieldwork began (Meissner 2000:Figures 45-48). A summary of the original scope of work for these three areas is as follows:

Area 1 - The ca. 1850 structure located in the southeast section of the park. A total of 10 shovel tests was planned around the structure to determine if there remained any associated intact deposits. Two of these tests were to be placed immediately adjacent the walls of the structure. If significant deposits or features were noted, $1 \times 1-\mathrm{m}$ test units were to be dug to further test the area.

Area 2 - A $30 \mathrm{~m}$ by $45 \mathrm{~m}$ area in the northwest quadrant of the park selected for construction of a new playground and an associated walkway. A total of 17 shovel tests was to be dug. If significant deposits or features were noted, $1 \times 1-\mathrm{m}$ test units were to be dug to further test the area.

Area 3 - An existing swing set in the southwestern portion of the park is to be replaced with new equipment. A total of seven shovel tests was to be dug. If significant deposits or features were noted, additional $1 \times 1-\mathrm{m}$ test units were to be dug to further test the area.

In addition, CAR was to monitor the digging of trenches approximately $10 \mathrm{in} .(25.4 \mathrm{~cm})$ wide and $14 \mathrm{in} .(35.5 \mathrm{~cm})$ deep for a new sprinkler system. The archaeologist monitoring the mechanical digging was to examine these trench profiles to determine if they contained dense archaeological deposits or undisturbed features. The goal of these examinations was to use the trenching to provide sample corridors through the park that could help further characterize the spatial distribution of archaeological deposits and disturbed areas, at least near the ground surface.
Given additional improvements proposed by the San Antonio Parks and Recreation Department and with Texas Historical Commission concurrence, four items were added to the original scope of work. One of these was the excavation along the east elevation of the Block House in order that the below-grade masonry be exposed for repointing. Also not included in the original scope of work was the monitoring of the grading around the Block House, in order to correct a recurring drainage problem. The third item that was added was the monitoring of the excavation of four areas along the old bandstand (see Figure 1) in order to expose and properly repoint the masonry joints. Finally, monitoring of the digging of holes for planting several trees near the old playground and the new swings was authorized via CAR's request to proceed and THC's concurrence of April 11, 2002 (letter on file at Center for Archaeological Research).

\section{Field $M$ ethods}

\section{Testing}

A total of 34 shovel tests was excavated and numbered sequentially as follows: Area 1-Block House, 10 shovel tests numbered ST2002-01-10; Area 2-New Playground, 17 shovel tests numbered ST2002-11-27; and Area 3-Old Swings, seven shovel tests numbered ST2002-28-34. All shovel tests were $40 \mathrm{~cm}$ in diameter and were excavated in $10-\mathrm{cm}$ arbitrary levels. Unless impeded by intrusions or bedrock, every shovel test (ST) was excavated to at least 70 $\mathrm{cm}$ below surface $(\mathrm{cmbs})$. A minimum of two shovel tests were excavated to depths greater than $70 \mathrm{cmbs}$ in each of the three areas. Given the known significance of deposits within San Pedro Springs Park, the shovel tests were located at 5-m intervals whenever possible.

All excavated sediments were screened through a 1/4-inch mesh. All cultural material retained within the screens was returned to the CAR lab for processing and analysis. A shovel test form was completed for every excavated shovel test. Data collected from each shovel test included the final excavation depth, a tally of all materials recovered from each $10-\mathrm{cm}$ level, and a brief soil description (texture, consistency, Munsell color, and inclusions). In most cases, a sketch profile of the shovel test was included on the data recovery form. The location of every shovel test was 


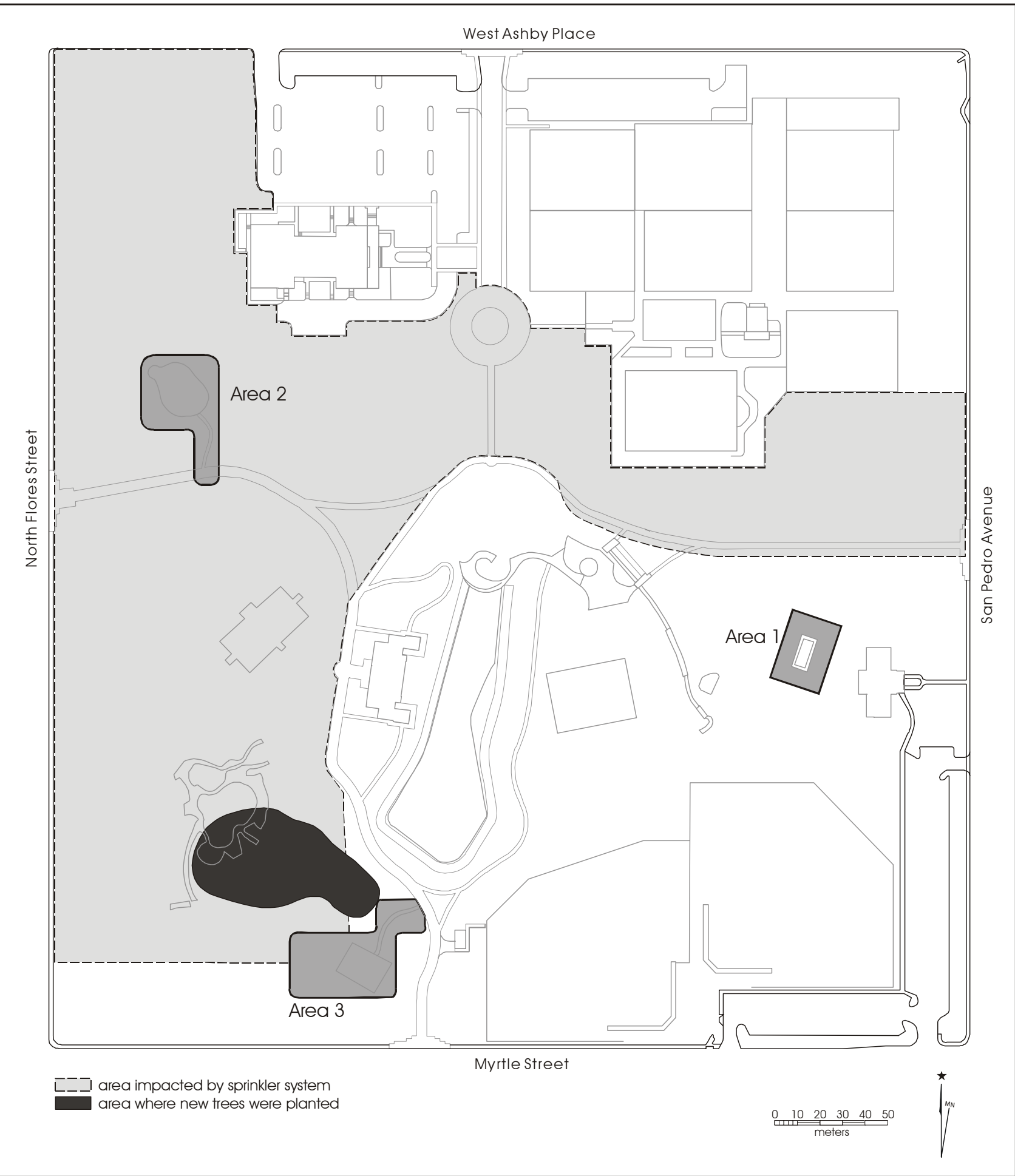

Figure 4. Location of park improvement impacts. 
precisely identified and located on a plan view of each of the three areas (Figures 5, 6, and 7).

\section{Area I - Block House}

This area is located in the southeastern quadrant of the park and centered around a $14 \mathrm{ft}$. by $40 \mathrm{ft} .(4 \mathrm{~m} \mathrm{x} 12 \mathrm{~m})$ historic structure referred to as the Block House (also known as the "Old Fort"). The construction plan proposed to grade the soil adjacent the structure to improve drainage. In addition, the plans call for exposing two-thirds of the foundation in order to fill this area in with sediments that will promote drainage away from the structure. In response to these impacts, a series of 10 shovel tests were planned for this area (Figure 5). Two shovel tests were located along the foundation; the remaining eight shovel tests were placed at 5 -m intervals. The original research design also proposed that if intact historic deposits were located, then a minimum of two 1 x 1-m units would be excavated in order to sample the extent of the deposits. Results of the shovel tests made it necessary to dig two $1 \times 1-\mathrm{m}$ test units. They were designated U2002-01 and U2002-02 (see Figure 5).

\section{Area 2 - New Playground}

This area is located in the northwest quadrant of the park where a new playground is planned for construction. The playground is to be constructed within a $20 \mathrm{~m}$ by $30 \mathrm{~m}$ area. The majority of the subsurface impact will involve sinking support piers approximately $60-105 \mathrm{~cm}(2-3.5 \mathrm{ft}$.) deep.

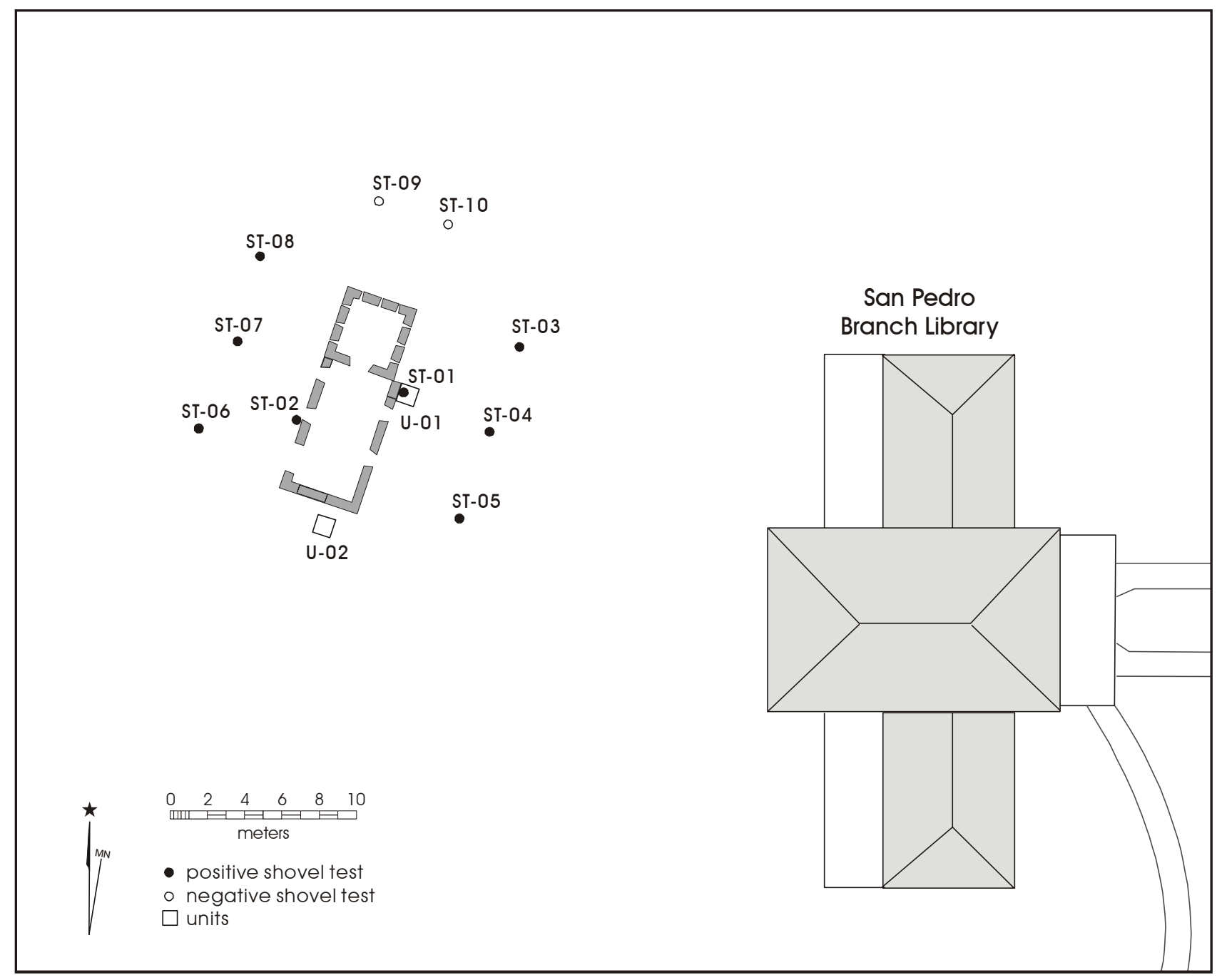

Figure 5. Placement of shovel tests and test units in Area 1-Block House. 


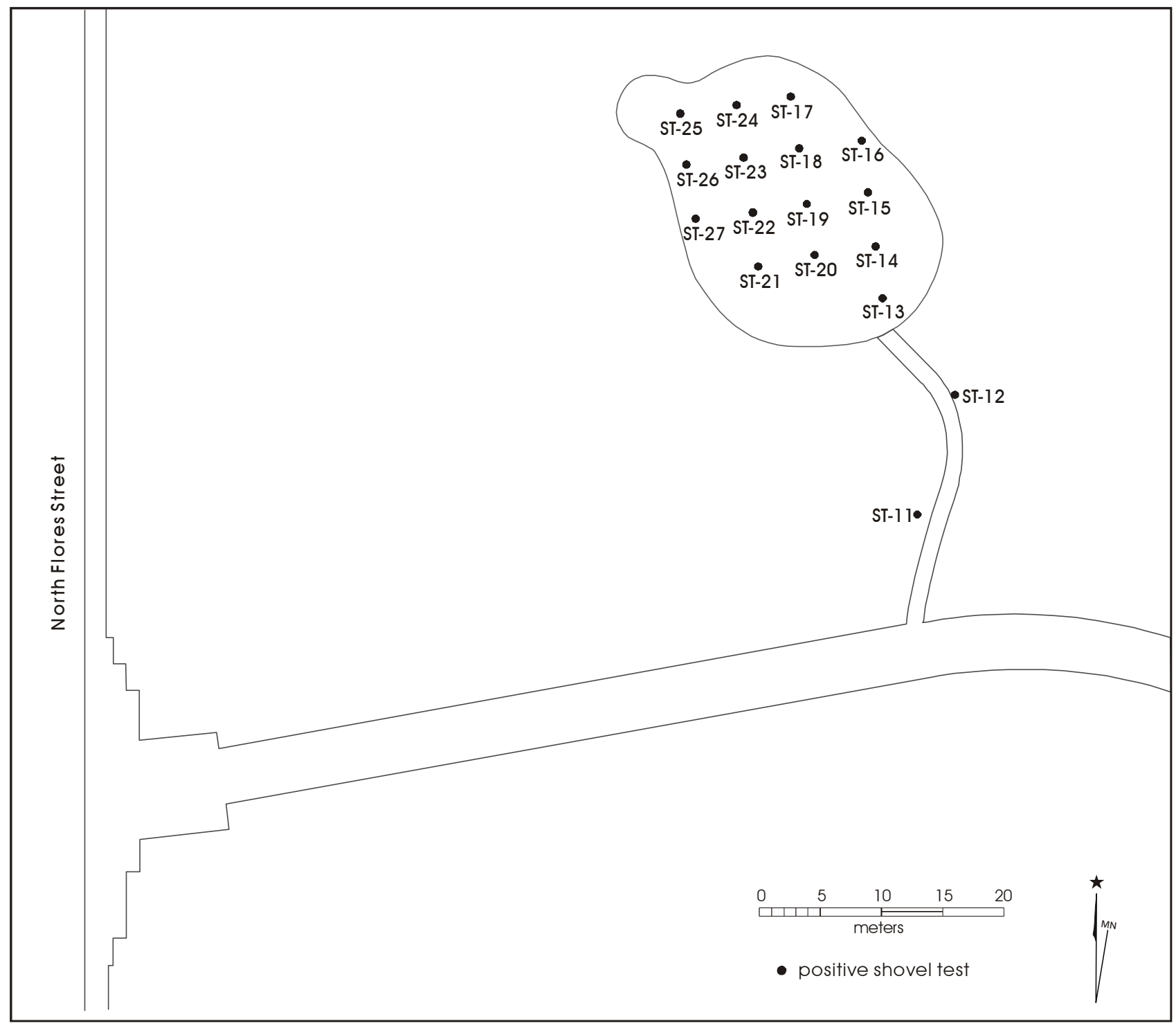

Figure 6. Locations of shovel tests in Area 2 - New Playground.

The research design called for a total of 15 shovel tests to be excavated within the proposed footprint of the playground area, in order to determine the presence of subsurface cultural resources. An additional two shovel tests were excavated along the footprint of the proposed $24 \mathrm{~m}$ by $1 \mathrm{~m}$ walkway. With the exception of these latter two shovel tests, the shovel tests were placed at 5-m intervals (Figure 6). The excavation of additional test units was not deemed necessary in this project area.

\section{Area 3 - Old Swings}

This area is located in the south-central part of the park where an existing set of swings is to be modified (see Figure 4). This area is approximately $15 \mathrm{~m}$ by $20 \mathrm{~m}$ and includes a 34-m-long by 1-m-wide walkway. A total of seven shovel tests was excavated in this area and placed between 5 and $20 \mathrm{~m}$ apart (Figure 7). These shovel tests were also $40 \mathrm{~cm}$ in diameter. The excavation of additional test units was not deemed necessary in this project area. 


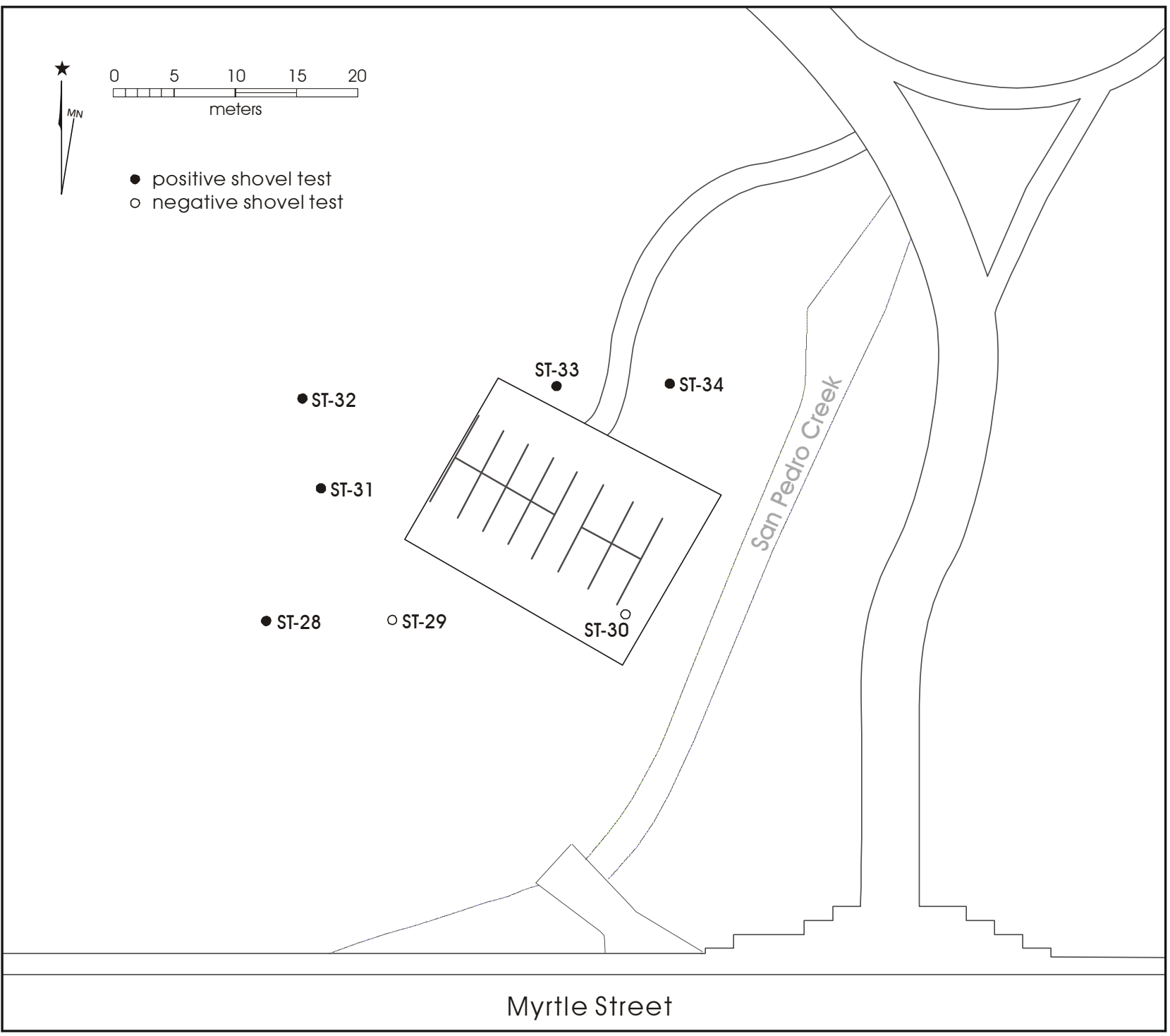

Figure 7. Location of shovel tests in Area 3 - Old Swings.

\section{M onitoring}

The majority of the monitoring consisted of observations of approximately $4,940 \mathrm{~m}$ of shallow trenches dug with a mechanical ditch digger. The width of each trench was approximately 10 in. $(25.4 \mathrm{~cm})$ and the depth of each was approximately $14 \mathrm{in} .(35.5 \mathrm{~cm})$. Trench walls were troweled to identify potential archaeological deposits. Informal inspection of backdirt was performed during this monitoring effort. Only those portions of the trenches that contained moderate or high densities of artifacts, or areas with features, were profiled. The cultural material, archaeological features, and amount of disturbance were recorded for all segments of the sprinkler irrigation system trenches examined. No artifacts were collected, but temporally diagnostic artifacts were noted.

The second part of the monitoring involved observing excavation of eight hand-dug holes for planting trees in the southwest quadrant of the park (Figure 8). The holes were 36 in. $(90 \mathrm{~cm})$ in diameter and 24 in. $(60 \mathrm{~cm})$ in depth. The excavated soils and exposed profiles were closely examined 


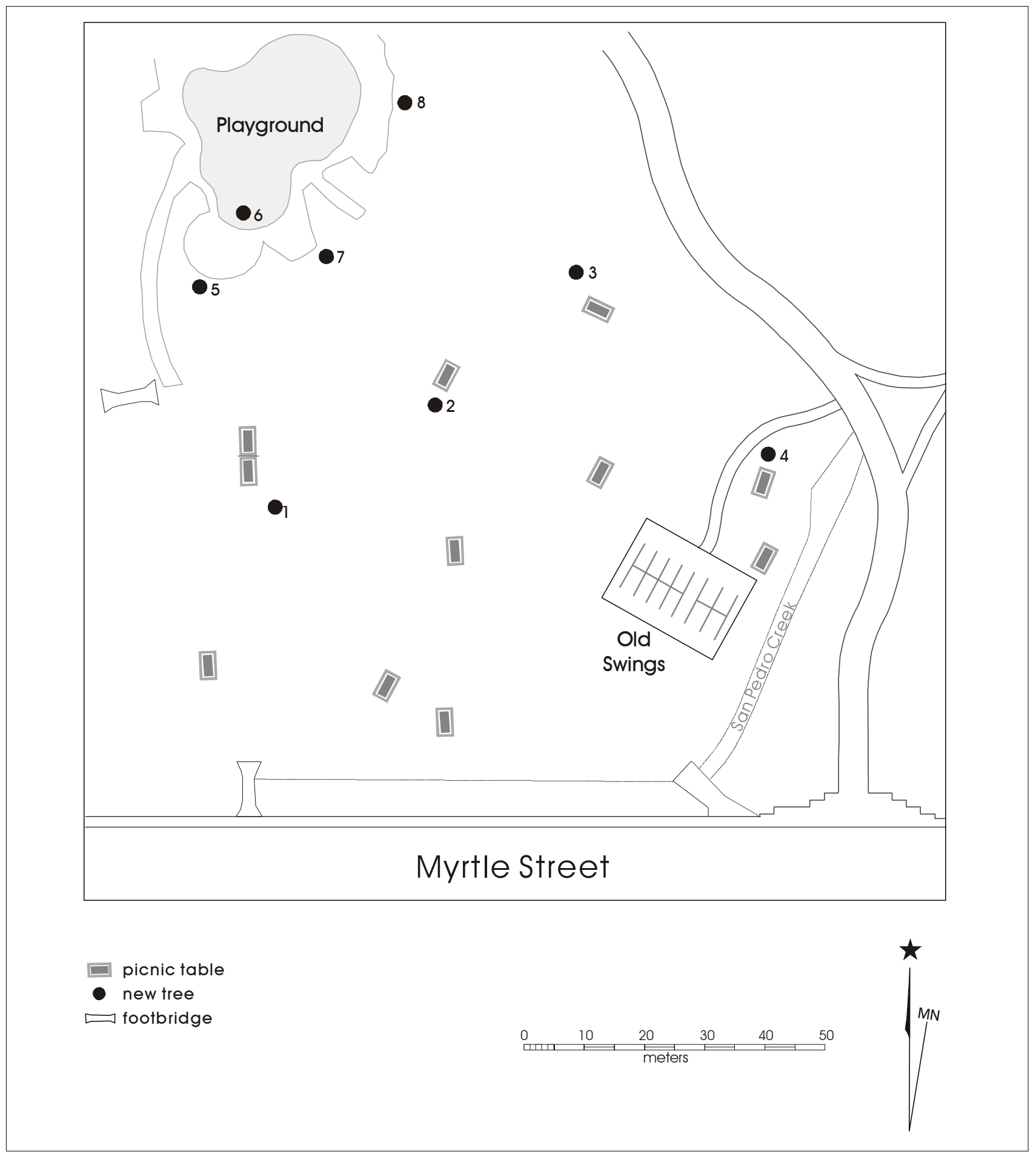

Figure 8. Locations of newly planted trees. 
for artifacts and/or features. The exact location of the trees was plotted on a plan view of the southwest quadrant, and the exposed stratigraphy was examined and two of the holes were profiled for future reference.

A trench $50 \mathrm{~cm}$ wide was dug along the south half of the east face of the Block House in order to expose the foundation for repointing. Very few artifacts were recovered, and all of these were modern in origin and were not collected.

CAR staff also monitored excavations under the bandstand near the main spring. This is the area described as a "Bear Pit" on old maps. In the area under the bandstand, workmen dug two 3-ft. $(.91 \mathrm{~m})$ square pits, one on the north end and one on the south end. The pits were about $1.5 \mathrm{ft}$. $(.46 \mathrm{~m})$ in depth, and were intended for setting concrete footers to support the new floor of the bandstand.

The sediments were a mix of caliche gravels and sandy loam, and were very wet. Limestone cobbles, $10-15 \mathrm{~cm}$ in greatest length, comprised about 10 percent of the fill. Larger rocks (ca. 20-50 cm in greatest length) comprised about two percent of the fill. There was a large quantity of glass fragments and numerous pieces of unidentifiable metal fragments. No artifacts were collected.

The final monitoring took place in October 2002, during renovation of the Block House. Changes were made in the surface grade around the structure with the intention of increasing water flow away from the base of the stone building. A staff archaeologist was present during the entire operation noting any artifacts that were uncovered and ensuring that no major feature or deposit was disturbed.

\section{Laboratory $M$ ethods}

All recovered artifacts were washed in tap water, air-dried, and placed in plastic bags with acid-free paper tags identifying provenience. Artifacts were examined and placed in one of the categories listed in Table 1. Items that could be dated were bagged separately. All recovered artifacts are curated at CAR.

Table 1. Artifact Classes

\begin{tabular}{|c|l|}
\hline Category & \multicolumn{1}{|c|}{ Examples } \\
\hline Kitchen/Household & $\begin{array}{l}\text { Ceramics, bottle glass, bottle caps, } \\
\text { utensils, etc. }\end{array}$ \\
\hline Personal & $\begin{array}{l}\text { Buttons, other clothing items, jewelry, } \\
\text { grooming items, pipes, coins, etc. }\end{array}$ \\
\hline Activities & Toys, games, writing items, etc. \\
\hline Arms & Cartridges, gun parts, etc. \\
\hline Barn/Workshop & Horseshoes, tools, machine parts, etc. \\
\hline Construction & $\begin{array}{l}\text { Nails, other hardware, building materials } \\
\text { brick, tile, window glass, etc.), utilities. }\end{array}$ \\
\hline Metal \& Other Misc. & $\begin{array}{l}\text { Metal items not included above. Paper, } \\
\text { unidentified plastic, charcoal, coal, } \\
\text { clinker, etc. }\end{array}$ \\
\hline Lithics & $\begin{array}{l}\text { Stone tools and debitage, ground stone, } \\
\text { burned rock. }\end{array}$ \\
\hline Organics & Bone, shell, seeds, etc. \\
\hline
\end{tabular}




\section{Chapter 4: $\quad$ Results of Investigations}

\section{Testing}

A summary of the results of excavation in each of the three areas is presented in this chapter. A total of 1,784 artifacts was recovered during the excavations. A discussion of the artifacts is presented in Chapter 5.

\section{A rea 1 - Block H ouse}

The soil survey for Bexar County identifies the native soil in this area as a Tarrant association (TaC). Tarrant soils are dark colored, very shallow, clayey and weakly calcareous (Taylor et al. 1991:30-31). This cap of native soil over bedrock is relatively shallow in Area 1, and is overlain by a series of fills, which differ from one area to the next. This variation is best illustrated in the discussion and illustrations related to the two excavated units. In most cases, the bedrock is located within $50 \mathrm{~cm}$ (20 in.) of the surface in Area 1. The bedrock is fractured into layers of limestone in a dark clayey matrix. The fractured limestone is granular and very coarse, with layers typically between $8 \mathrm{~cm}$ and $10 \mathrm{~cm}(3-4$ in.) thick.

Ten shovel tests (STs) were excavated within the vicinity of the Block House (Figure 5). A total of 458 artifacts was recovered in these tests. The results of the shovel tests indicated a need for more testing. Two additional 1 x $1-\mathrm{m}$ units were excavated; one along the east wall of the building, surrounding ST2002-01, and one $1.5 \mathrm{~m}$ south of the south face of the building (see Figure 5). An additional 991 artifacts were recovered in the two test units for a total of 1,449 for all of Area 1. This represents 81.2 percent of the total count of artifacts recovered during this project. Table 2 presents the artifacts recovered in Area 1 by general artifact class, unit, and level. Note that ST2002-01 and U2002-01 were combined in Table 2, since the latter is just an expansion of the former.

\section{Shovel Tests}

ST2002-01 was excavated against the east elevation of the Block House, and ST2002-02 against the west elevation. These shovel tests were both purposefully located between a window and door opening in order to maximize the possibility of identifying activity areas and related artifacts. In both cases, these shovel tests were only excavated to 40 cmbs. ST2002-01 was stopped at $40 \mathrm{cmbs}$ since it was felt that it would be more efficient to extend this excavation to a
1 x 1-m unit. ST2002-02 was stopped after hitting a layer of concrete/plaster at $40 \mathrm{cmbs}$, as it was felt prudent not to break through this feature.

Distinct artifact deposits were located at ST2002-03, ST2002-04, and ST2002-06 (see Figure 5). ST2002-03 was culturally sterile from 6 to $40 \mathrm{cmbs}$, and then produced nine artifacts from between 40 and 43 cmbs. ST2002-04 was culturally sterile from 5 to $38 \mathrm{cmbs}$, and then produced eight artifacts from between 38 and 42 cmbs. ST2002-05 produced a nineteenth-century rifle bullet casing fragment and construction-related material from the first level (see Chapter 5). ST2002-06 was culturally sterile from 20 to 52 $\mathrm{cmbs}$, and then produced 64 artifacts from between 52 and 57 cmbs. ST2002-07 and ST2002-08, northwest of the Block House, contained few artifacts. All levels in ST2002-09 and ST2002-10 proved to be culturally sterile. Both of these shovel tests were located to the north of the structure. The soils were comprised of about $4 \mathrm{~cm}$ of sod and between 26 and $46 \mathrm{~cm}$ of culturally sterile, sandy clay loam that probably represents modern fill. The limestone bedrock was encountered at about $30 \mathrm{cmbs}$ in ST2002-09 and $50 \mathrm{cmbs}$ in ST2002-10.

\section{Test Units}

It was hoped that by enlarging ST2002-01 the archaeologists would be able to examine and document the foundation of the stone building in greater detail. However, this was not possible owing to the intrusion of a large tree root (Figure 9). Given the size of the tree root and how it was embedded in the wall footer, no attempt to remove it was made for fear of undermining the structural integrity of the wall. The unit was excavated to the fractured bedrock at $50 \mathrm{cmbs}$. Figure 10 depicts the stratigraphy of the north wall profile of U2002-01. The plinth noted in Figure 10 is part of the wall footer. It extends away from the east elevation wall, and is typically about six to eight inches wider than the abovegrade wall.

A total of 840 artifacts was recovered from Unit 2002-01. When combined with the 245 artifacts recovered from ST2002-01, the number is an impressive 1,085. Layer 4 (40-48 cmbs) of U2002-01 slopes away from the structure, probably to allow for drainage. Datable artifacts from this unit indicate that all levels are at least somewhat mixed. Wire nails and clear glass (sun-stained amber/yellow) were 
Table 2. Summary of Artifacts Recovered from Area 1 - Block House

\begin{tabular}{|c|c|c|c|c|c|c|c|c|c|c|c|c|c|}
\hline Level & 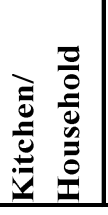 & 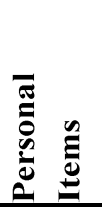 & : & $\stackrel{n}{E}$ & 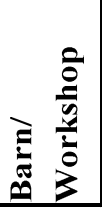 & 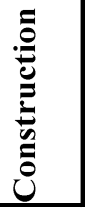 & 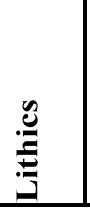 & 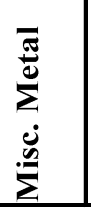 & $\stackrel{e}{\dot{e}}$ & $\stackrel{\mathscr{0}}{\stackrel{0}{0}}$ & 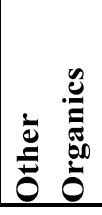 & Total & $\begin{array}{c}\text { Total } \\
\text { for Unit }\end{array}$ \\
\hline \multicolumn{14}{|c|}{ ST2002-01 \& U2002-01 (excavated to $50 \mathrm{cmbs}$ ) } \\
\hline Lvl. 1 & 228 & 4 & 1 & & & 25 & 1 & 12 & 1 & 2 & & 274 & \multirow{5}{*}{1085} \\
\hline Lvl. 2 & 18 & 1 & & & 1 & 67 & 1 & 36 & 5 & 6 & & 135 & \\
\hline Lvl. 3 & 37 & 7 & 1 & 3 & 1 & 171 & 8 & 95 & 4 & 71 & 1 & 399 & \\
\hline Lvl. 4 & 24 & 5 & 4 & & & 80 & 1 & 50 & 1 & 40 & 1 & 206 & \\
\hline Lvl. 5 & 11 & & & & & 26 & 10 & 14 & 1 & 9 & & 71 & \\
\hline \multicolumn{14}{|c|}{ U2002-02 (excavated to $50 \mathrm{cmbs}$ ) } \\
\hline Lvl. 1 & 34 & 1 & & & 1 & 15 & & 22 & & 1 & & 74 & \multirow{4}{*}{152} \\
\hline Lvl. 2 & 5 & 1 & & & & 1 & 2 & 32 & & . & & 41 & \\
\hline Lvl. 3 & 1 & 2 & & & & 2 & & 7 & & 1 & & 13 & \\
\hline Lvl. 4 & 6 & & & & & 1 & 3 & 10 & & 4 & & 24 & \\
\hline \multicolumn{14}{|c|}{ ST2002-02 (excavated to $40 \mathrm{cmbs}$ ) } \\
\hline Lvl. 1 & 5 & & & & & 5 & & 4 & & & & 14 & \multirow{4}{*}{82} \\
\hline Lvl. 2 & 5 & & & & & 8 & & & & & & 13 & \\
\hline Lvl. 3 & 13 & & & & & 28 & & 5 & & & & 46 & \\
\hline Lvl. 4 & 2 & & & & & 1 & & 5 & 1 & & & 9 & \\
\hline \multicolumn{14}{|c|}{ ST2002-03 (excavated to $43 \mathrm{cmbs}$ ) } \\
\hline Lvl. 1 & & & & & & & & 1 & & & & 1 & \multirow{2}{*}{11} \\
\hline Lvl. 5 & 1 & & & & & 1 & & 6 & & 2 & & 10 & \\
\hline \multicolumn{14}{|c|}{ ST2002-04 (excavated to $42 \mathrm{cmbs})$} \\
\hline Lvl. 1 & 1 & & & & & & & & & & & 1 & \multirow{2}{*}{9} \\
\hline Lvl. 4 & 5 & & & & & & 1 & & & 2 & & 8 & \\
\hline \multicolumn{14}{|c|}{ ST2002-05 (excavated to $50 \mathrm{cmbs}$ ) } \\
\hline Lvl. 1 & & & & 1 & & 1 & & & & & & 2 & 2 \\
\hline \multicolumn{14}{|c|}{ ST2002-06 (excavated to $57 \mathrm{cmbs}$ ) } \\
\hline Lvl. 1 & & & & & 1 & 4 & & 1 & & & & 6 & \multirow{4}{*}{76} \\
\hline Lvl. 2 & & 1 & & & & 1 & & 2 & & & & 4 & \\
\hline Lvl. 5 & 14 & & & & & 5 & 1 & 10 & & 2 & & 32 & \\
\hline Lvl. 6 & 10 & 1 & & & & 5 & 1 & 12 & 1 & 4 & & 34 & \\
\hline \multicolumn{14}{|c|}{ ST2002-07 (excavated to $27 \mathrm{cmbs}$ ) } \\
\hline Lvl. 1 & 1 & & & & & 5 & & & & & & 6 & \multirow{2}{*}{22} \\
\hline Lvl. 2 & 9 & & & & & & & 7 & & & & 16 & \\
\hline \multicolumn{14}{|c|}{ ST2002-08 (excavated to $25 \mathrm{cmbs}$ ) } \\
\hline Lvl. 1 & 2 & & & & & & & & & & & 2 & \multirow{3}{*}{10} \\
\hline Lvl. 2 & 7 & & & & & & & & & & & 7 & \\
\hline Lvl. 3 & 1 & & & & & & & & & & & 1 & \\
\hline
\end{tabular}




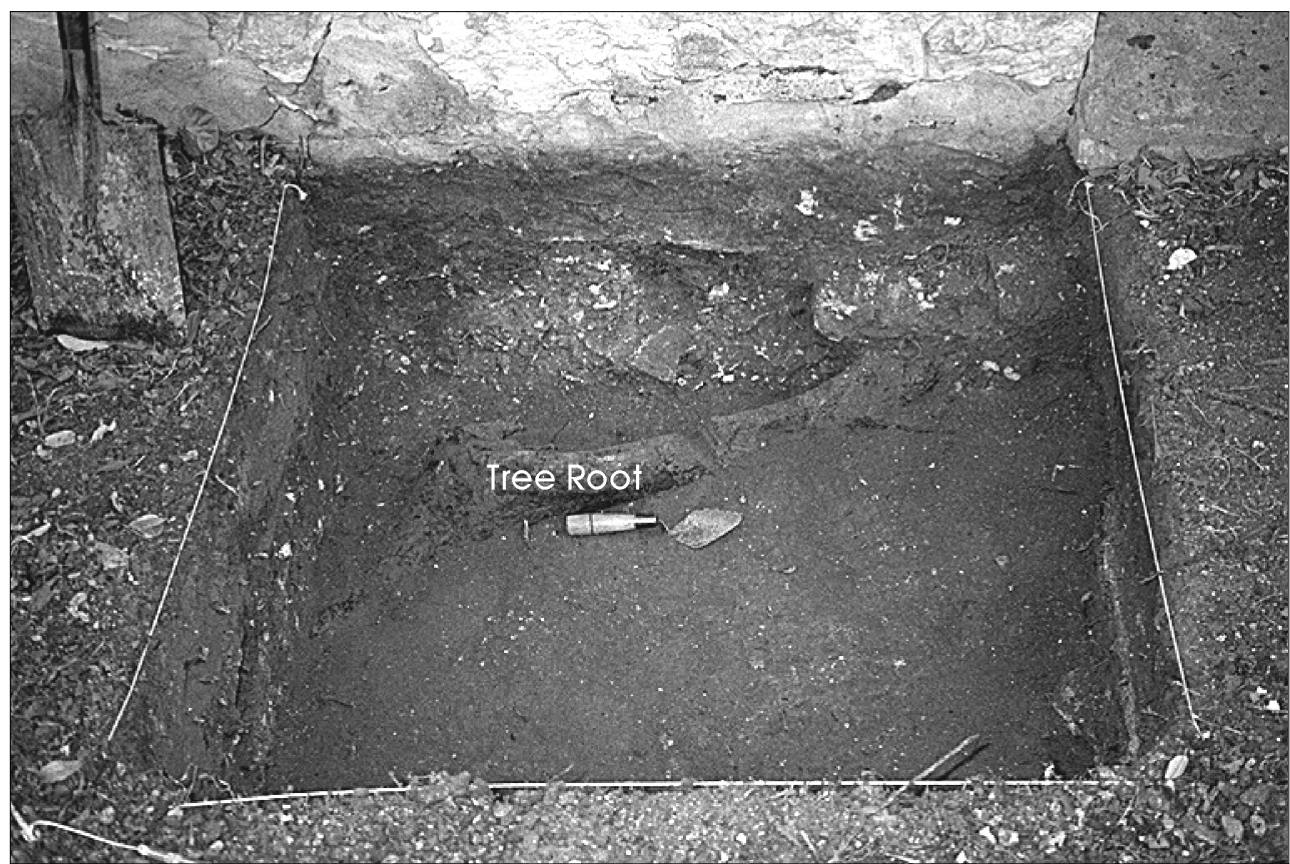

Figure 9. U2002-01 at $30 \mathrm{~cm}$, showing large tree root piercing the foundation.

recovered from the lowest levels of the unit. Both artifact types are twentieth-century indicators (see Chapter 5), however, the majority of the datable artifacts from this unit are mid- or late-nineteenth-century in origin. and 11). A mixture of nineteenth- and twentieth-century artifacts were recovered. Lithic debitage $(n=25)$ and one untypeable dart point were recovered from Area 1, but all were in association with historic material.
A second unit, U2002-02, was excavated along the south elevation of the structure. This unit was located $1.5 \mathrm{~m}$ south of the wall (Figure 5) since there were no shovel tests in that area. The unit was placed as near to the wall as possible, and near the location of an old door in the south wall. The placement of the unit was meant to increase the chances of recovering additional artifacts and/ or exposing additional features or architectural details. While additional artifacts were recovered, no additional features were located. The soil stratigraphy in this area was quite different from that along the east elevation (Figure 11).

The number of artifacts recovered from U200202 was not as high as that recovered from U200201 (Table 2). Only 152 artifacts were recovered from this unit. Five distinct sediment layers were identified and, even though U2002-01 was located $12 \mathrm{~m}$ to the north, the soils did not resemble those encountered in U2002-01 (compare Figures 10

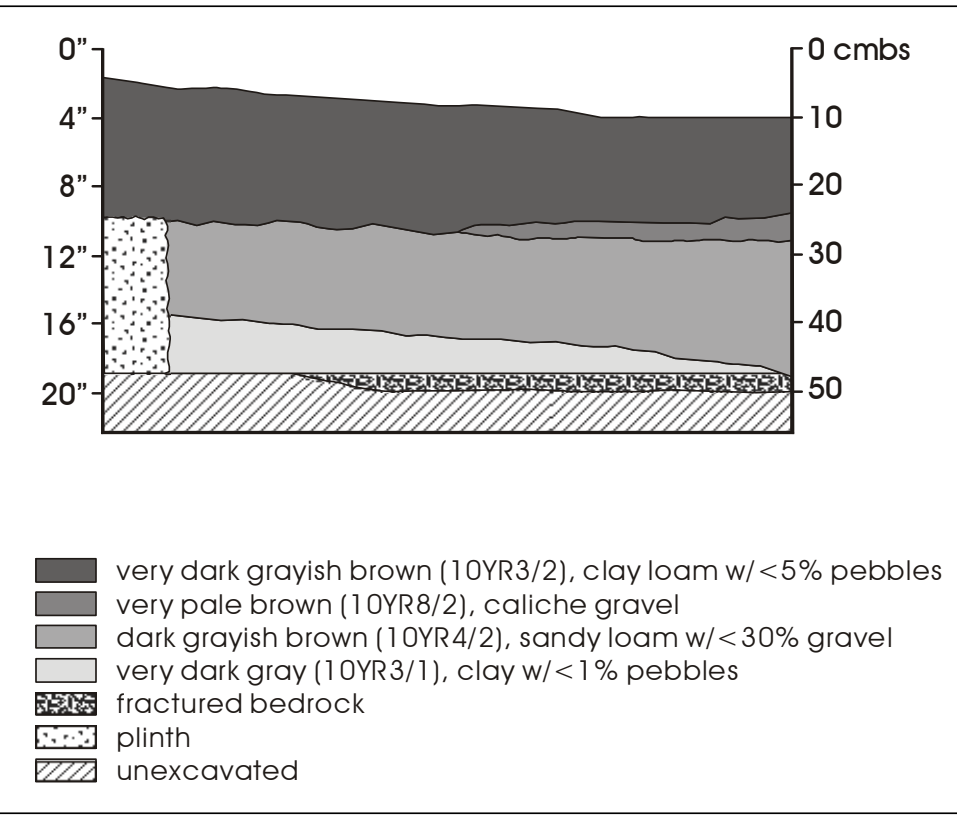

Figure 10. Profile of north wall of U2002-01. 


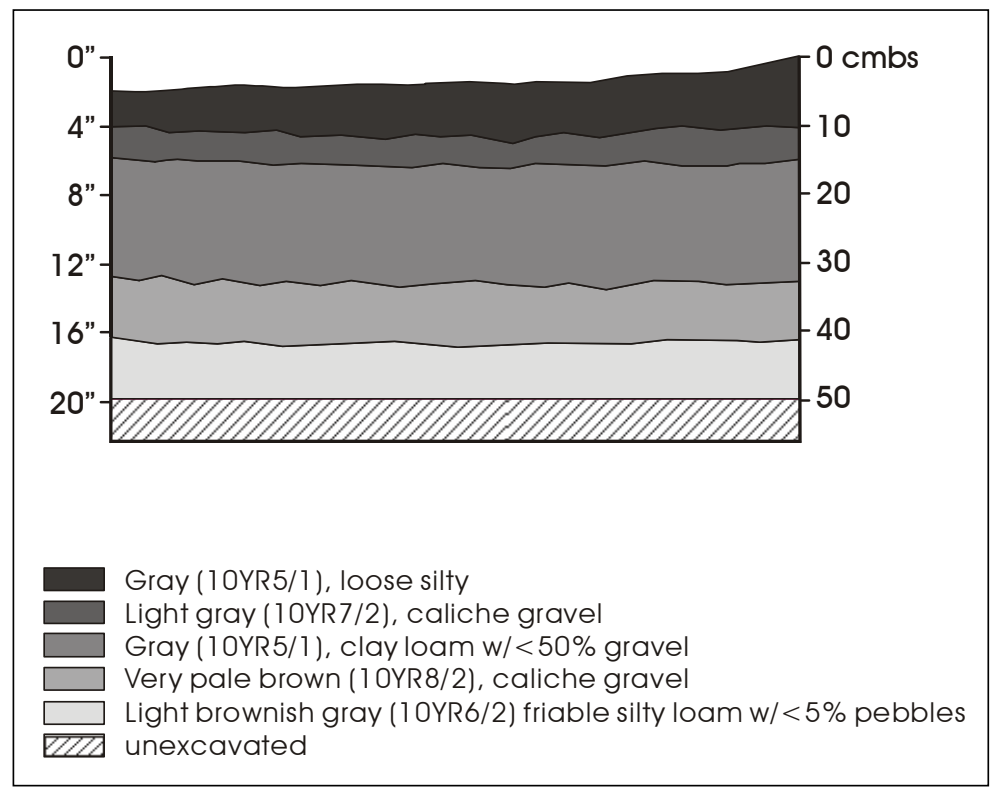

Figure 11. Profile of north wall of U2002-02.

\section{A rea 2 - $\mathrm{N}$ ew Playground}

A total of 15 shovel tests was excavated within the proposed footprint of the new playground and an additional two shovel tests were excavated along the planned walkway (Figure 6). Owing to obstructions, two of the 15 shovel tests were stopped between 37 and $40 \mathrm{cmbs}$. As called for in the scope of work, two of the shovel tests were excavated to between 70 and $80 \mathrm{cmbs}$.

A total of 302 artifacts was recovered from Area 2 (see Table $3)$. The majority of the recovered material is Kitchen/ Household items, mostly assorted vessel glass ( $\mathrm{n}=145,47.5$ percent). Most of this glass is probably modern in origin, however, one bottle fragment may have an applied lip, suggesting a nineteenth-century origin. A single piece of
Colonial-period ceramic was recovered from Level 5 (40$50 \mathrm{cmbs}$ ) of ST2002-22. This was a tiny fragment of burnished Tonalá ware (see Chapter 5).

Lithic material comprised 5.9 percent of the total $(\mathrm{n}=18)$. Eleven of the 17 (64.7 percent) shovel tests produced lithic material, about 33 percent $(n=6)$ of which came from what might be considered undisturbed contexts (that is, in levels below the historic artifacts recovered). These possibly undisturbed contexts were present in ST2002-13 and ST2002-16.

ST2002-12 and ST2002-24 were both excavated to about $80 \mathrm{cmbs}$. Two pieces of debitage, one piece of glass, and 37 snake vertebrae were recovered from ST2002-12, between 70 and $80 \mathrm{cmbs}$. ST2002-24 was sterile from 40 to $80 \mathrm{cmbs}$. 
Table 3. Summary of Artifacts Recovered from Area 2 - New Playground

\begin{tabular}{|c|c|c|c|c|c|c|c|c|c|c|c|c|}
\hline Level & 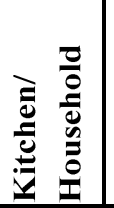 & 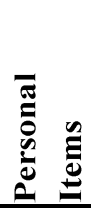 & : & $\stackrel{\mathscr{E}}{\underline{E}}$ & 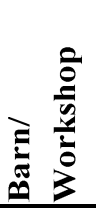 & 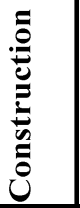 & 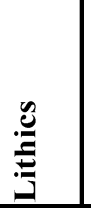 & $\begin{array}{l}\bar{\pi} \\
\sum_{0}^{0} \\
\dot{0} \\
\dot{0} \\
\sum\end{array}$ & 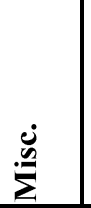 & $\stackrel{\mathscr{0}}{0}$ & Total & $\begin{array}{c}\text { Total } \\
\text { for Unit }\end{array}$ \\
\hline \multicolumn{13}{|c|}{ ST2002-11 (excavated to $55 \mathrm{cmbs})$} \\
\hline Lvl. 2 & 5 & & & & & & & & & & 5 & \multirow{3}{*}{19} \\
\hline Lvl. 4 & 6 & & & & & 1 & 1 & & & & 8 & \\
\hline Lvl. 6 & 2 & & & & & 1 & 3 & & & & 6 & \\
\hline \multicolumn{13}{|c|}{ ST2002-12 (excavated to $80 \mathrm{cmbs}$ ) } \\
\hline Lvl. 1 & 1 & & & & & 1 & & 1 & & & 3 & \multirow{6}{*}{64} \\
\hline Lvl. 2 & 6 & & & & & 1 & & & & & 7 & \\
\hline Lvl. 3 & & & & & & 1 & & & & & & \\
\hline Lvl. 4 & & & & & & 1 & & & & & & \\
\hline Lvl. 6 & & & & & & & 1 & 13 & & & 14 & \\
\hline Lvl. 8 & 1 & & & & & & 21 & & & 37 & 40 & \\
\hline \multicolumn{13}{|c|}{ ST2002-13 (excavated to $70 \mathrm{cmbs}$ ) } \\
\hline Lvl. 1 & 4 & & & & & & & & & & 4 & \multirow{4}{*}{9} \\
\hline Lvl. 3 & 1 & & & & & 1 & & & & & 2 & \\
\hline Lvl. 4 & & & & & 1 & & & & & & 1 & \\
\hline Lvl. 7 & & & & & & & 2 & & & & 2 & \\
\hline \multicolumn{13}{|c|}{ ST2002-14 (excavated to $70 \mathrm{cmbs}$ ) } \\
\hline Lvl. 3 & 5 & & & & & & & & & & 5 & \multirow{2}{*}{18} \\
\hline Lvl. 4 & 13 & & & & & & & & & & 13 & \\
\hline \multicolumn{13}{|c|}{ U2002-15 (excavated to $70 \mathrm{cmbs}$ ) } \\
\hline Lvl. 2 & 2 & & & & & & & & & & 2 & \multirow{3}{*}{11} \\
\hline Lvl. 4 & & & & & & & & 5 & & 1 & 6 & \\
\hline Lvl. 5 & 2 & & & & & 1 & & & & & 3 & \\
\hline \multicolumn{13}{|c|}{ ST2002-16 (excavated to $70 \mathrm{cmbs}$ ) } \\
\hline Lvl. 1 & 3 & & & & & 1 & & & & & 4 & \multirow{5}{*}{14} \\
\hline Lvl. 2 & & & & & & 1 & & & & & 1 & \\
\hline Lvl. 3 & 3 & & & & & 2 & & & & & 5 & \\
\hline Lvl. 6 & & & & & & & 2 & & & & 2 & \\
\hline Lvl. 7 & & & & & & & 2 & & & & 2 & \\
\hline \multicolumn{13}{|c|}{ ST2002-17 (excavated to $40 \mathrm{cmbs})$} \\
\hline Lvl. 1 & & & & & & 1 & 1 & & 1 & & 3 & \multirow{4}{*}{17} \\
\hline Lvl. 2 & 6 & & & & & & 1 & & & & 7 & \\
\hline Lvl. 3 & 3 & & & & & & & & & & 3 & \\
\hline Lvl. 4 & 2 & & & & & 2 & & & & & 4 & \\
\hline \multicolumn{13}{|c|}{ ST2002-18 (excavated to $70 \mathrm{cmbs}$ ) } \\
\hline Lvl. 1 & 1 & & & & & & & & & & 1 & \multirow{5}{*}{22} \\
\hline Lvl. 2 & 4 & & & & & 1 & & & 1 & & 6 & \\
\hline Lvl. 3 & 2 & & & & & 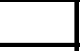 & & 2 & & & 4 & \\
\hline Lvl. 4 & 3 & & & & & 2 & & & 2 & & 7 & \\
\hline Lvl. 5 & & & & & & 3 & & 1 & & & 4 & \\
\hline
\end{tabular}


Table 3 . continued...

\begin{tabular}{|c|c|c|c|c|c|c|c|c|c|c|c|c|}
\hline Level & 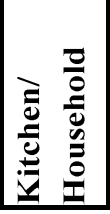 & 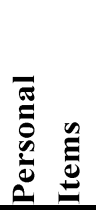 & 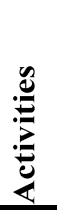 & $\stackrel{\varrho}{z}$ & 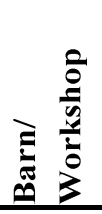 & 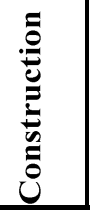 & $\frac{\mathscr{e}}{3}$ & 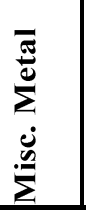 & 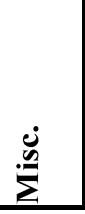 & $\stackrel{\mathscr{Z}}{0}$ & Total & $\begin{array}{c}\text { Total } \\
\text { for Unit }\end{array}$ \\
\hline \multicolumn{13}{|c|}{ ST2002-19 (excavated to $37 \mathrm{cmbs}$ ) } \\
\hline Lvl. 1 & 1 & & & & & & & & & & 1 & \multirow{4}{*}{48} \\
\hline Lvl. 2 & 8 & & & & & & 2 & 1 & 1 & 2 & 14 & \\
\hline Lvl. 3 & 15 & & & & & 4 & 1 & 6 & 1 & & 27 & \\
\hline Lvl. 4 & 3 & & & & & & & 3 & & & 6 & \\
\hline \multicolumn{13}{|c|}{ ST2002-20 (excavated to $70 \mathrm{cmbs}$ ) } \\
\hline Lvl. 2 & 1 & & & & & & 1 & & & & 2 & \multirow{4}{*}{9} \\
\hline Lvl. 3 & 2 & & & & & & & & & & 2 & \\
\hline Lvl. 4 & 2 & & & & & & & & & & 2 & \\
\hline Lvl. 5 & 3 & & & & & & & & & & 3 & \\
\hline \multicolumn{13}{|c|}{ ST2002-21 (excavated to $70 \mathrm{cmbs}$ ) } \\
\hline Lvl. 1 & & & & & & 1 & & & 2 & & 3 & \multirow{3}{*}{11} \\
\hline Lvl. 2 & 4 & & & & & 2 & & & & & 6 & \\
\hline Lvl. 3 & 2 & & & & & & & & & & 2 & \\
\hline \multicolumn{13}{|c|}{ ST2002-22 (excavated to $70 \mathrm{cmbs}$ ) } \\
\hline Lvl. 1 & 1 & & & & & 1 & 1 & 1 & & & 4 & \multirow{3}{*}{10} \\
\hline Lvl. 2 & 1 & & & & 1 & 2 & & & & & 4 & \\
\hline Lvl. 5 & 1 & & & & & & & & 1 & & 2 & \\
\hline \multicolumn{13}{|c|}{ ST2002-23 (excavated to $60 \mathrm{cmbs}$ ) } \\
\hline Lvl. 1 & & & & & & & & & & & 1 & \multirow{3}{*}{9} \\
\hline Lvl. 3 & 1 & & & & & 1 & & 5 & & & 7 & \\
\hline Lvl. 5 & & & & & & 1 & & & & & 1 & \\
\hline \multicolumn{13}{|c|}{ ST2002-24 (excavated to $80 \mathrm{cmbs})$} \\
\hline Lvl. 1 & 1 & & & & & & & & & & 1 & \multirow{3}{*}{16} \\
\hline Lvl. 2 & 6 & & & & & & & & & & 6 & \\
\hline Lvl. 3 & 5 & & & & & 1 & & 1 & 2 & & 9 & \\
\hline \multicolumn{13}{|c|}{ ST2002-25 (excavated to $70 \mathrm{cmbs}$ ) } \\
\hline Lvl. 1 & 3 & & & & & & & & & & 3 & \multirow{4}{*}{13} \\
\hline Lvl. 2 & 2 & & & & & & 1 & & & & 3 & \\
\hline Lvl. 3 & 4 & & & & & 1 & & 1 & & & 6 & \\
\hline Lvl. 5 & 1 & & & & & & & & & & 1 & \\
\hline \multicolumn{13}{|c|}{ ST2002-26 (excavated to $40 \mathrm{cmbs}$ ) } \\
\hline Lvl. 2 & 2 & & & & & & 1 & & & & 3 & 3 \\
\hline \multicolumn{13}{|c|}{ ST2002-27 (excavated to $70 \mathrm{cmbs})$} \\
\hline Lvl. 1 & 1 & & & & & & & & & & 1 & \multirow{3}{*}{9} \\
\hline Lvl. 3 & & & & & & 1 & & 3 & & & 4 & \\
\hline Lvl. 4 & & 1 & & & & 3 & & & & & 4 & \\
\hline
\end{tabular}




\section{A rea 3 - O ld swings}

Seven shovel tests were dug in Area 3 (Figure 7). All but two were excavated to $70 \mathrm{cmbs}$, and two of the seven were dug to $75 \mathrm{cmbs}$.

A total of 28 artifacts was recovered (Table 4). Two of the seven shovel tests were culturally sterile and five of the shovel tests did not contain any cultural material below $50 \mathrm{cmbs}$. Of these five shovel tests, three were culturally sterile from 40 to $70 \mathrm{cmbs}$. The artifacts appear to be in secondary context.

\section{M onitoring}

\section{M onitoring of Tree Planting}

This was a one-day monitoring activity that was carried out by CAR archaeologists in response to the planting of eight trees (Figure 8). The impacted area was located within the southwest quadrant of the park and within the immediate vicinity of the Area 3 shovel testing. Eight 36 -inch diameter holes were hand-excavated to a depth of 24 inches, under the supervision of a staff archaeologist.

Table 4. Summary of Artifacts Recovered from Area 3 - Old Swings

\begin{tabular}{|c|c|c|c|c|c|c|c|c|c|c|c|c|}
\hline Level & 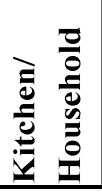 & 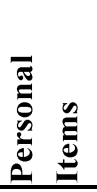 & : & $\stackrel{\varrho}{E}$ & 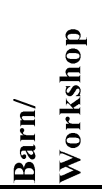 & 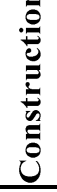 & 葛 & 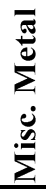 & $\stackrel{\dot{0}}{\ddot{\Sigma}}$ & $\stackrel{\mathscr{0}}{\mathscr{0}}$ & Total & $\begin{array}{c}\text { Total } \\
\text { for Unit }\end{array}$ \\
\hline \multicolumn{13}{|c|}{ ST2002-28 (excavated to $75 \mathrm{cmbs}$ ) } \\
\hline Lvl. 1 & 3 & & 1 & & & & & & 1 & & 5 & \multirow{3}{*}{11} \\
\hline Lvl. 2 & 1 & 1 & 1 & & 1 & & & & & & 4 & \\
\hline Lvl. 3 & & & & & & & & & & & 2 & \\
\hline \multicolumn{13}{|c|}{ ST2002-31 (excavated to $70 \mathrm{cmbs}$ ) } \\
\hline Lvl. 1 & 1 & & & & & & & & & & 1 & \multirow{3}{*}{4} \\
\hline Lvl. 2 & 1 & & & & & & & & & & 1 & \\
\hline Lvl. 3 & 1 & & & & & & & & & 1 & 2 & \\
\hline \multicolumn{13}{|c|}{ ST2002-32 (excavated to $70 \mathrm{cmbs}$ ) } \\
\hline Lvl. 4 & & & & & & & & & & & 1 & 1 \\
\hline \multicolumn{13}{|c|}{ ST2002-33 (excavated to $75 \mathrm{cmbs}$ ) } \\
\hline Lvl. 2 & 6 & & & & & & 1 & & 1 & & 8 & \multirow{2}{*}{9} \\
\hline Lvl. 3 & 1 & & & & & & & & & & 1 & \\
\hline \multicolumn{13}{|c|}{ ST2002-34 (excavated to $70 \mathrm{cmbs}$ ) } \\
\hline Lvl. 2 & 2 & & & & & & & & & & 2 & \multirow{2}{*}{3} \\
\hline Lvl. 4 & & & & & & & & & 1 & & 1 & \\
\hline
\end{tabular}


Most of the deposits within the holes consisted of fill. This location is within the same area tested by Houk (1999), which he designated as Transect $\mathrm{G}$ (six shovel tests). Houk (1999:17) makes note of an intact deposit in one of the six shovel tests, but with a low density of artifacts. In contrast, the only artifacts encountered during this part of the project were observed within the first 3-4 inches of sediments and all were of modern origin.

\section{M onitoring of the Installation of a Sprinkler System}

CAR archaeologists monitored the installation of sprinkler lines between February and June 2002. The installation of water lines required the excavation of $10 \mathrm{in}$. wide by $12 \mathrm{in}$. deep trenches. Almost one-half of the park was impacted by this activity (see Figure 4). The trenches totaled approximately 4,940 linear meters. Results of this monitoring can be seen in Figure 12.

Trenching along the northwest and southwest quadrants located remnants of abandoned parking lots and park roads. Occasional fragments of glass and pull-tabs, and other picnic-related materials were noted throughout the project area, but not collected. Also noted were occasional PVC and cast iron water lines no longer in use.

Most of the trenching in the east-central portion of the park, just south of the McFarlin Tennis Center, seemed to be through fill. The fill was caliche mixed with very sandy loam and varying amounts of broken limestone rubble. There were occasional examples of window glass and unidentifiable metal scraps in this fill. In some areas there was a much higher percentage of limestone rubble, and the pieces of rubble were much larger, averaging about $30 \mathrm{~cm}$. A 2-inch cast iron pipe (abandoned water line) was encountered, running parallel to the walkway in the northeastern quadrant of the park.

Most of the trenches had an occasional piece of bottle or window glass, however, one area in the northeastern quadrant south of the tennis courts had a dense collection of historic artifacts that appeared to represent a trash midden. The artifacts observed included at least three horseshoe fragments, numerous pieces of carbon rods from electrical arc lights, numerous pieces of window glass of various thicknesses, numerous fragments of bottle glass, several fragments of a glass electric insulator, several fragments of undecorated whiteware and one fragment of flow blue decorated whiteware, several wire nails, a railroad spike, and a few unidentifiable metal scraps. This deposit is noted on Figure 12. The insulator fragment had enough lettering on it to identify the Hemingray Co., which was in operation from about 1848 to 1933 (Moulton 2002). The type of flow blue decoration on the sherds was common around 1850 (Stelle 2001). One piece of undecorated whiteware had a partial maker's mark on it, but only the letters "PRUSSI..." and part of a design were readable. Goods imported into the U.S. were required to have their country of origin on them beginning in 1891 (Stelle 2001).

Together, the artifacts in this midden suggest a latenineteenth and early-twentieth-century origin, but there is no way to know if the artifacts originated in the park, or were deposited in their current location in fill brought in from elsewhere.

A second trash deposit was discovered just west of the tennis courts. As with the first trash deposit, the artifacts may be in (at least) secondary context in the park.

There were a few areas where sediments appeared natural and undisturbed. These are marked on Figure 12. The long trench down the western edge of the park is in the old drainage ditch that was filled after 1998. No artifacts were seen in the areas of caliche fill. In other areas where the sediment is less disturbed, there were a few pieces of bottle glass, an occasional brick fragment, and wire nails.

Remnants of the old parking lot west of the current lot located north of the playhouse were visible in many trenches in the northwest quadrant. South of the playhouse, most of the sediments were not obviously disturbed, but there was an occasional brick or metal fragment seen in the profile. One large flake (ca. $8 \mathrm{~cm}$ long) and occasional bits of broken bottles were observed in this area. One bottle bottom had markings identified as belonging to the Seaboard Glass Bottle Co., which operated from 1943 to 1947 (Toulouse 1971:445). One fragment of a horseshoe was also noted.

One area, south of the Playhouse building, was of interest. It appeared to be a filled-in trench, $5 \mathrm{~m}$ wide, with large limestone blocks on the edges and fist-sized limestone rubble and sand mixed with caliche. The walls appeared to be perpendicular, but the irrigation trench did not reach the bottom so there was no way to tell how deep it is. The limestone all appeared to be of the local variety. This feature may have been part of a walkway associated with the 


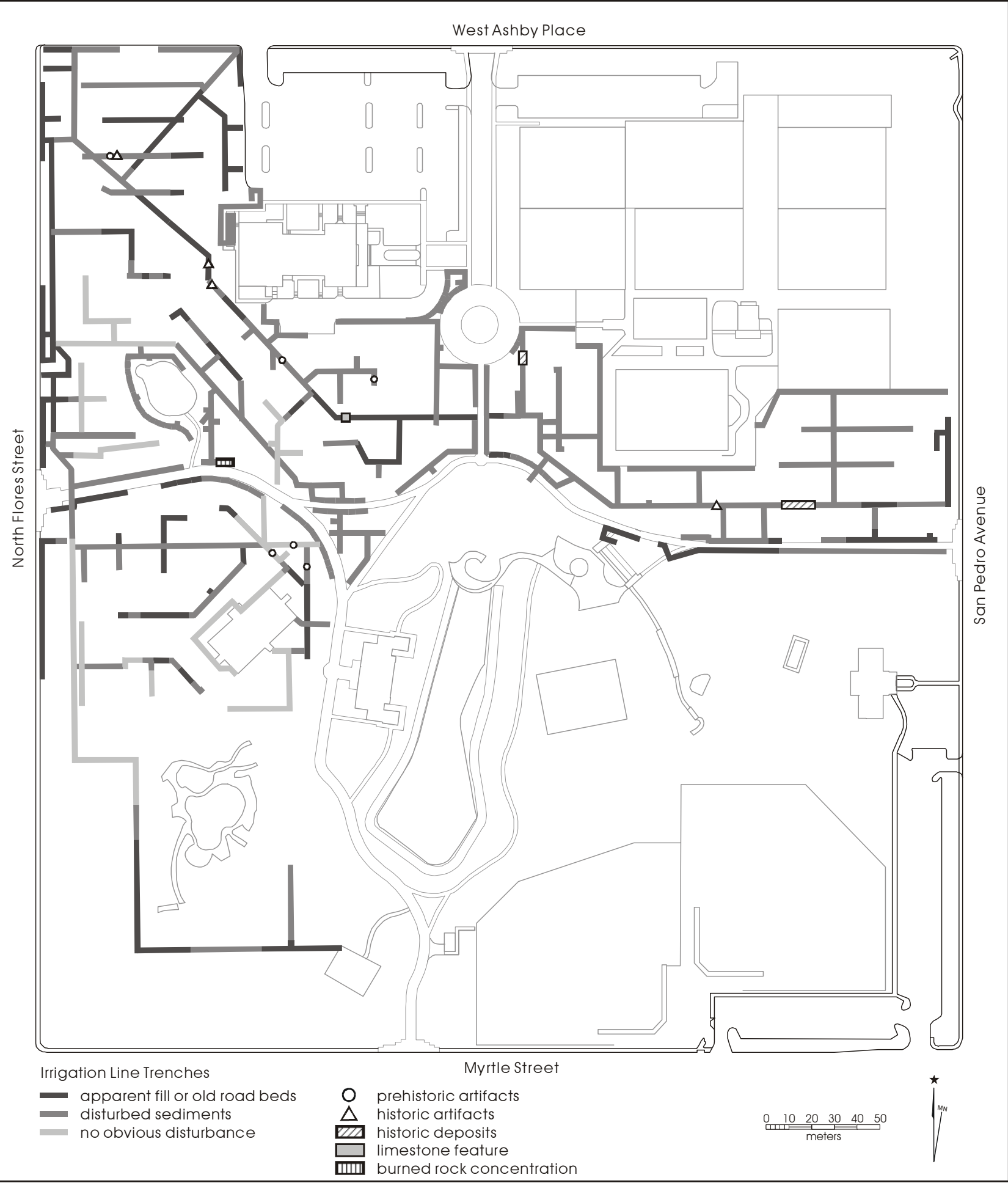

Figure 12. Results of monitoring trenches for sprinkler system lines. 
amphitheater that was once located just north of the triangular section of pathway in the middle of the park (Figure 12).

Just north of the area designated Region 3 on Figure 3, the trenching machine scraped across the top of a small burned rock concentration, buried roughly $30 \mathrm{~cm}$ (12 in.) below ground surface. A few chert flakes were also noted in association. The extent and depth of this feature are not known at this time.

Trenching along the southwest quadrant, close to Myrtle Street, continued to unearth evidence of abandoned park roads and parking areas. A few artifacts were noted in the backdirt, and these were comprised of a mix of nondiagnostic historic glass and late-twentieth-century material. This was the last area of the park that was trenched. 


\section{Chapter 5:}

\section{The A rtifacts}

This chapter presents a brief discussion of each artifact type recovered, with emphasis on those items that are temporally diagnostic or otherwise of interest. A provenienced artifact catalog is available from CAR upon request.

\section{Kitchen/ $\mathrm{H}$ ousehold}

Most of the items relating to the kitchen and household are, in this case, probably not domestic items at all. By far the largest category in this artifact class is bottle glass, most of which probably once held various types of drinks, both alcoholic and nonalcoholic.

\section{Ceramics}

Ceramics were a very small portion of the total inventory. Only 42 ceramic sherds were collected (Table 5 ). The largest group of ceramics is undecorated white earthenwares $(\mathrm{n}=20$, 47 percent). The flow blue decoration was first developed about 1825 and was in use until early in the twentieth century (Yakubik 1990:303). The type of flow blue in this collection is probably from the 1850s (Stelle 2001). The other decorated white earthenwares suggest an early- to midnineteenth-century origin (Stelle 2001).

Only one ceramic sherd may be of Colonial origin. This is the fragment of burnished Tonalá ware recovered from Level 5 (40-50 cmbs) of ST2002-22.

\section{Glass}

Fragments of glass bottles and other containers were the largest single artifact category $(\mathrm{n}=468$, including ink bottle fragments listed under Activities). Most were unidentifiable glass fragments (Table 6). Of these, only three were a shade of olive green often seen in Colonial glass. Two more sherds were a very dark olive green often called "Black" glass. This type of glass was common in the first half of the nineteenth century (Munsey 1970).

Two other colors are temporally diagnostic. During the last quarter of the nineteenth century until 1915 (Munsey 1970:55), manganese was added to glass as a decolorizer, i.e., to make the glass appear clear. When this type of glass is exposed for some time to sunlight it gradually changes to
Table 5. Ceramics

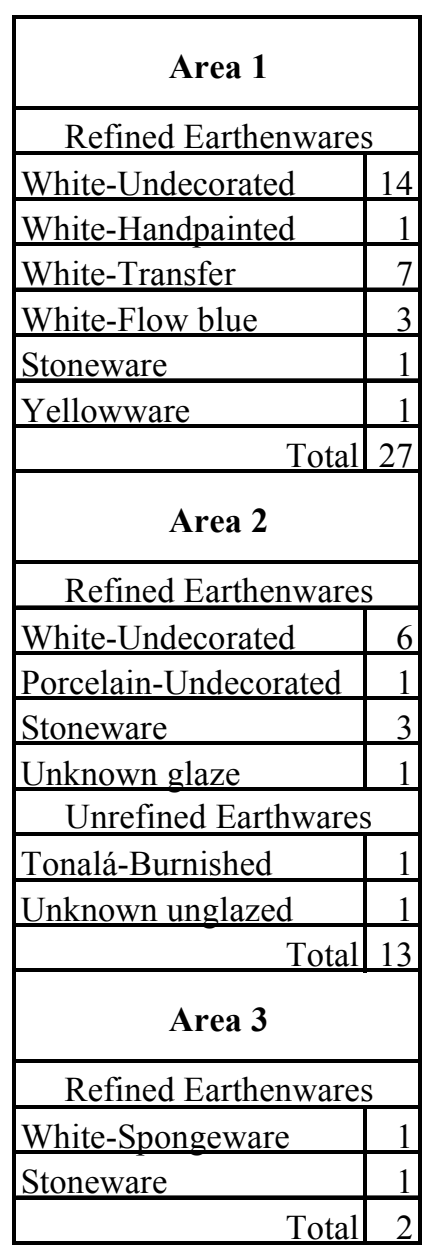

Table 6. Glass fragments

\begin{tabular}{|c|c|}
\hline \multicolumn{2}{|l|}{ Area 1} \\
\hline Color & Ct. \\
\hline "Black" & 2 \\
\hline Olive & 3 \\
\hline Aqua & 8 \\
\hline Brown & 139 \\
\hline Clear & 96 \\
\hline Clear (selenium) & 17 \\
\hline Green & 85 \\
\hline Total & 350 \\
\hline \multicolumn{2}{|l|}{ Area 2} \\
\hline Color & $\mathrm{Ct}$. \\
\hline Aqua & 9 \\
\hline Brown & 29 \\
\hline Clear & 42 \\
\hline Clear (amethyst) & 1 \\
\hline Milk glass & 1 \\
\hline Blue & 1 \\
\hline Green & 3 \\
\hline Total & 86 \\
\hline \multicolumn{2}{|l|}{ Area 3} \\
\hline Color & Ct. \\
\hline Aqua & 3 \\
\hline Brown & 2 \\
\hline Clear & 5 \\
\hline Green & 1 \\
\hline Total & 11 \\
\hline
\end{tabular}

a shade of lavender or amethyst. After the beginning of World War I, American bottle makers were cut off from their major supply of manganese in Germany. They switched to using selenium. This type of glass, when exposed to sunlight, gradually changes to a amber or yellow shade. Selenium was used as a decolorizer until about 1930 when arsenic (which does not change color in the sun) became the most common chemical used for this purpose (Munsey 1970:55). Only a single piece of amethyst glass was recovered (from Area 2). Twenty pieces of amber/yellow glass were recovered in Area 1. 
The numbers and kinds of glass items recovered during this project are consistent with use of the park as a gathering place during both the nineteenth and twentieth centuries (Table 7).

\section{O ther Kitchen/ $\mathrm{H}$ ousehold Items}

The remaining items in this artifact class are listed in Table 8 . These are very few in number and reflect the absence of more than temporary residential use of the park.

\section{A ctivities}

Only nine activity-related items were recovered -all related to either play or writing activities. One piece of blackboard slate and one slate pencil were recovered. Fragments of an ink bottle were found in ST2002-01 (Figure 13). This aqua glass bottle was molded and a lip applied; a nineteenthcentury technique (Munsey 1970).

Table 7. Diagnostic glass

\begin{tabular}{|c|c|c|c|}
\hline \multicolumn{4}{|r|}{ Area 1} \\
\hline Color & Type & Location & Description \\
\hline $\begin{array}{l}\text { Clear/Sun-stained } \\
\text { amber/yellow }\end{array}$ & $\begin{array}{l}\text { Drinking } \\
\text { glass }\end{array}$ & $\begin{array}{l}\text { U2002-01, } \\
\text { ST2002-01, } \\
\text { ST2002-06, } \\
\text { ST2002-07 }\end{array}$ & $\begin{array}{l}4 \text { fragments of a large glass with decorative etched } \\
\text { bands. Probably a beer glass. }\end{array}$ \\
\hline Aqua & Unknown & U2002-01 & $\begin{array}{l}\text { Fragment of a glass tube } 15 \mathrm{~mm} \text { in diameter. The } \\
\text { glass is } 2.5 \mathrm{~mm} \text { thick, making it unlikely to be test } \\
\text { tube or tube from florescent lighting. Use unknown. }\end{array}$ \\
\hline Clear & $\begin{array}{l}\text { Bottle } \\
\text { bottom }\end{array}$ & U2002-01 & $\begin{array}{l}\text { Fragment of oval shape, with lettering " } 24 / 73 \text { " on } \\
\text { bottom. }\end{array}$ \\
\hline Clear & $\begin{array}{l}\text { Bottle } \\
\text { fragment }\end{array}$ & U2002-01 & $\begin{array}{l}\text { Fragment with portion of the back half of an elephant } \\
\text { embossed on it. }\end{array}$ \\
\hline Clear & Bottle lip & U2002-01 & Machine-made lip (post-1903) \\
\hline \multicolumn{4}{|r|}{ Area 2} \\
\hline Color & Type & Location & Description \\
\hline Clear & $\begin{array}{l}\text { Bottle } \\
\text { fragment }\end{array}$ & ST2002-14 & $\begin{array}{l}3 \text { fragments, probably from the same bottle (based on } \\
\text { color, condition, and thickness of glass), with } \\
\text { embossed lettering. }\end{array}$ \\
\hline Clear & Bottle lip & ST2002-17 & Fragment, possibly with applied lip. \\
\hline Clear & $\begin{array}{l}\text { Bottle } \\
\text { fragment }\end{array}$ & ST2002-17 & Fragment with "Quar..." \\
\hline Clear & Bottle lip & ST2002-24 & Machine-made screw cap lip (post-1903) \\
\hline Clear & Bottle lip & ST2002-24 & Machine-made screw cap lip (post-1903) \\
\hline Clear & Bottle base & ST2002-26 & $\begin{array}{l}\text { Very thick bottle base with "...NAN..." embossed on } \\
\text { side. Probably a soda water bottle. }\end{array}$ \\
\hline \multicolumn{4}{|r|}{ Area 3} \\
\hline Color & Type & Location & Description \\
\hline Green & Bottle base & ST2002-34 & Round base with "...D/80-13..." on side. \\
\hline
\end{tabular}


Table 8. Other Kitchen/Household Items

\begin{tabular}{|c|c|c|}
\hline \multicolumn{3}{|c|}{ Area 1} \\
\hline \multirow{3}{*}{ Container tops } & Crown cap & 2 \\
\hline & Pull tab & 5 \\
\hline & Plastic tab & 1 \\
\hline Oil lamps & Chimney glass & 43 \\
\hline \multirow[t]{2}{*}{ Utensils } & Flatware handle & 1 \\
\hline & Spoon & 1 \\
\hline \multicolumn{2}{|r|}{ Total } & 53 \\
\hline \multicolumn{3}{|c|}{ Area 2} \\
\hline \multirow{2}{*}{ Container tops } & Crown cap & 3 \\
\hline & Pull tab & 1 \\
\hline Oil lamps & Chimney glass & 1 \\
\hline \multicolumn{2}{|r|}{ Total } & 5 \\
\hline \multicolumn{3}{|c|}{ Area 3} \\
\hline \multirow{2}{*}{ Container tops } & Crown cap & 1 \\
\hline & Pull tab & 1 \\
\hline & Total & 2 \\
\hline
\end{tabular}

Six toy items were recovered. A small fragment of a porcelain doll hand, probably from a cloth-bodied ceramic doll, was recovered in Area 1. The lid of a doll-sized teapot was also recovered in Area 1. This was made of lead, suggesting a nineteenth-century or early-twentieth-century origin. At that time, lead was often used to mold small cheap items that would later be made of plastic.

In Area 3, a small white plastic figure of a soldier was recovered (Figure 14a). This was only the upper part of the body, with the remains of glue on the bottom. It probably was part of a jeep or some other vehicle.

Three marbles were recovered. One was a handmade glass, opaque, multicolored swirl that dates to ca. 1880 (Figure 14b). Another of the marbles was a clay, white "commie" that also dates to ca. 1880 (Figure 14c). Both of these marbles were recovered from Area 1. The third was a machine-made glass, agate swirl that dates to ca. 1950 (Zapata 1997), found in Area 3 (Figure 14d).

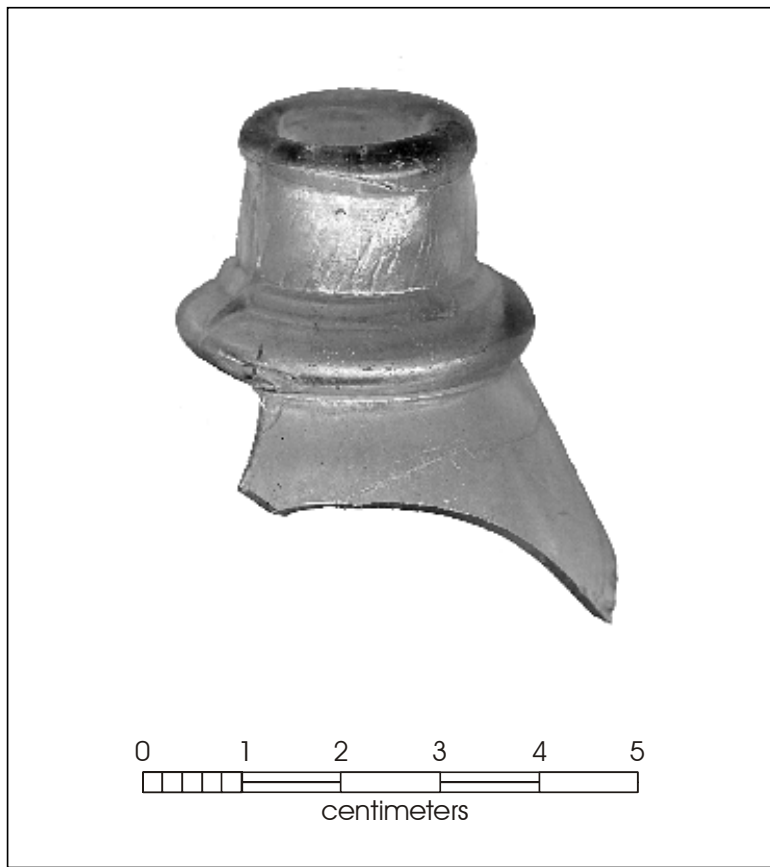

Figure 13. Nineteenth-century ink bottle fragment.

\section{Personal Items}

A total of 22 Personal items was recovered (Table 9). Within this category, the highest number of items was buttons $(\mathrm{n}=14)$. Thirteen of the buttons were recovered from Area 1, the Block House. The buttons were bone, shell, ceramic, glass, and metal. Shell buttons were most popular between about 1880 and 1920 (Pool 1987:289). Most of the shell buttons in this collection were at least partially handmade, based on the unevenness of the holes (Figure 15a and b). One button in particular is made on an unevenly cut blank, with holes drilled from both sides with a triangular shaped drill bit and small indentations added for decoration (Figure $15 \mathrm{c})$. This button is probably from the mid-nineteenth century or possibly earlier.

One button fragment was made of bone, with five holes (Figure 15d). The fifth hole is a by-product of the manufacturing technique and dates the button to between 1830 and 1850 (Pool 1987:283). 


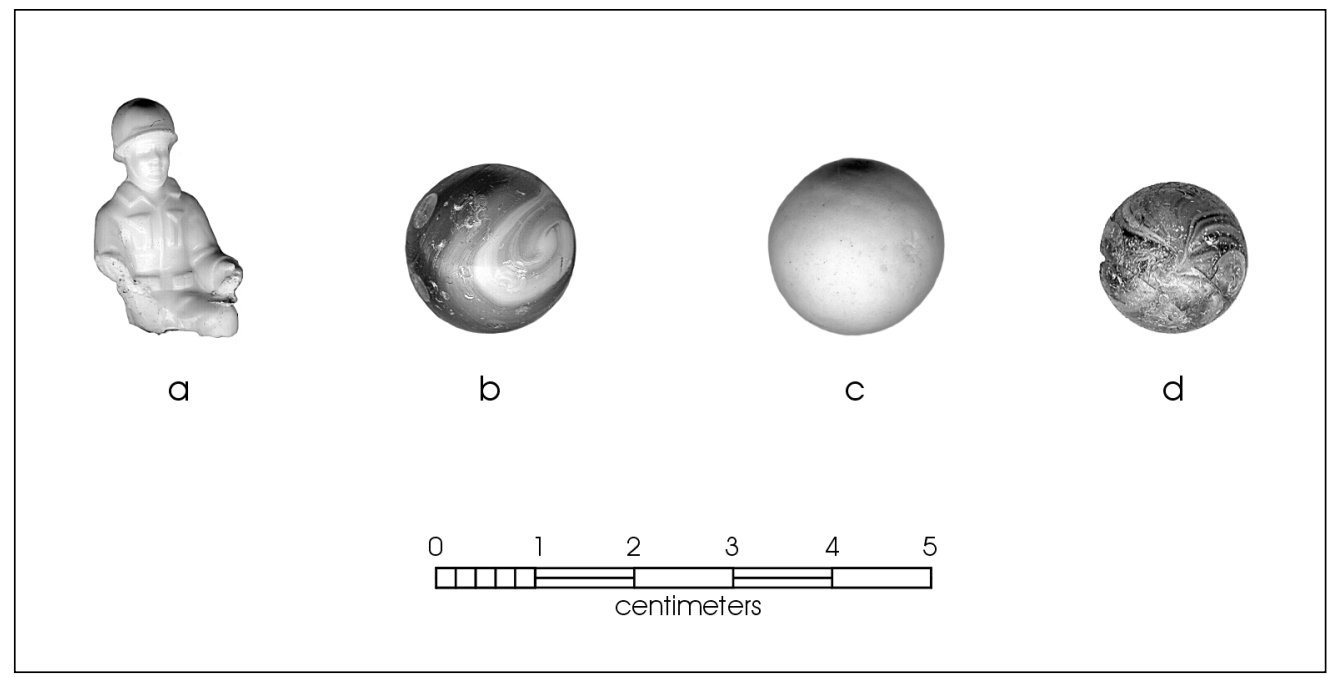

Figure 14. Toys: a) Plastic toy soldier; b) glass marble; c) clay marble; d) glass marble.

Table 9. Personal Items

\begin{tabular}{|c|c|}
\hline \multicolumn{2}{|l|}{ Area 1} \\
\hline Buttons-Ceramic & 6 \\
\hline Buttons-Glass & 1 \\
\hline Buttons-Bone & 1 \\
\hline Buttons-Shell & 4 \\
\hline Buttons-Metal & 1 \\
\hline Jewelry-glass jewel & 1 \\
\hline Jewelry-Crucifix & 1 \\
\hline Coins & 3 \\
\hline Pipe stem fragment & 1 \\
\hline Mirror glass & 1 \\
\hline Total & 20 \\
\hline \multicolumn{2}{|l|}{ Area 2} \\
\hline Medical-syringe fragment & 1 \\
\hline Total & 1 \\
\hline \multicolumn{2}{|l|}{ Area 3} \\
\hline Buttons-Metal & 1 \\
\hline Total & 1 \\
\hline
\end{tabular}

Six ceramic buttons were recovered. Ceramic buttons were most popular between 1850 and 1910 (Pool 1987:289). Examples of the two most common types, the dish type and the pie crust type, are shown in Figure 15e and f, respectively. A black glass button is shown in Figure 15g. It was probably in use during the last half of the nineteenth century, when the mourning of Queen Victoria set the fashion for many years (Meissner 1997:168; Pool 1987:288).

Two metal buttons were recovered. One was very rusted and the other appeared to be made of aluminum (Figure $15 \mathrm{~h}$ ). It had at one time been painted dark blue, but most of the paint has been worn off.

Two jewelry items were recovered, both from Area 1. One was a large amber glass jewel, $13 \mathrm{~mm}$ by $28.8 \mathrm{~mm}$. The second was a very cheaply made copper alloy crucifix (Figure 16). This item is not readily dateable. Similar crosses have been found in Colonial contexts (see Plate 21 in Schuetz 1969), but were still being made well into the twentieth century.

Three coins were recovered during the project, all from Area 1. Two were pennies dated 1996 and the third was a silver quarter dollar dated 1856 (Figure 17). 


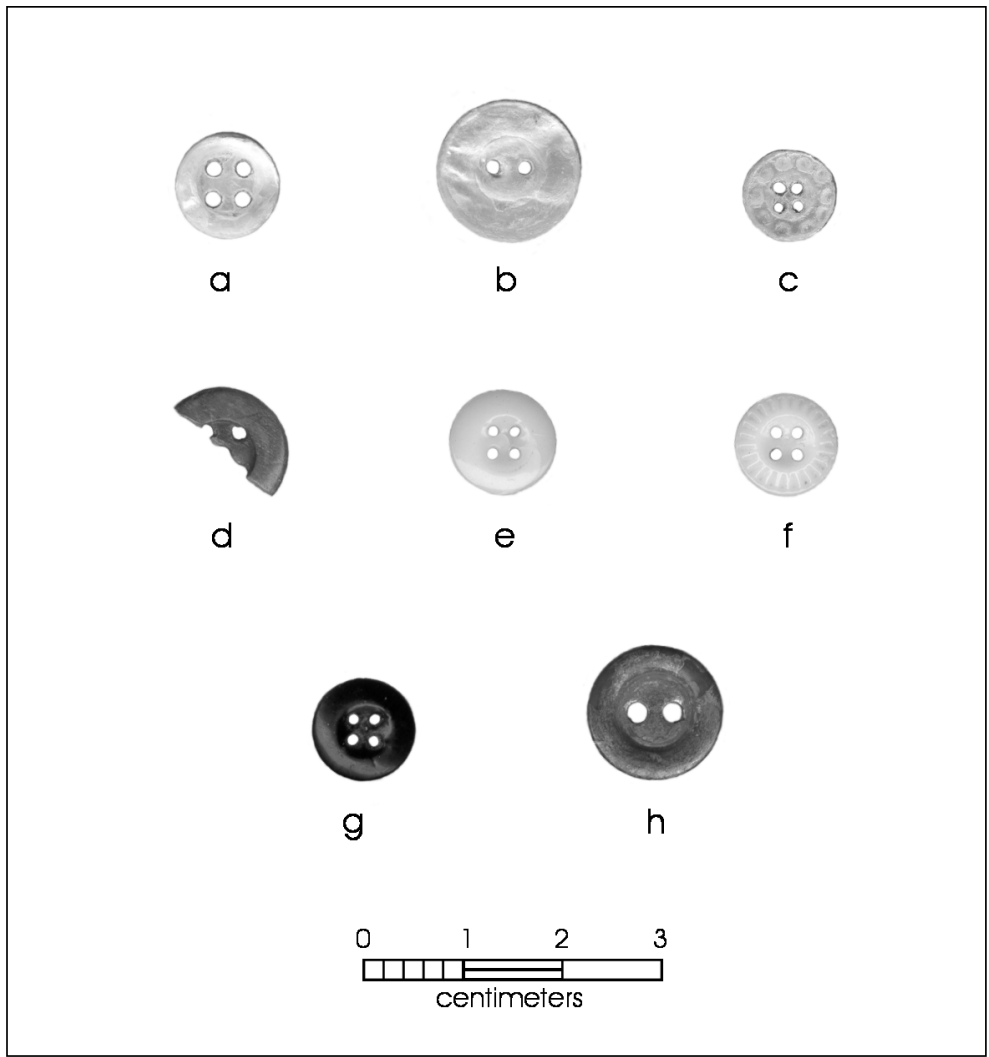

Figure 15. Personal Items: a-c) shell buttons; d) bone button; e-f) ceramic buttons; g) glass button; h) painted metal button.

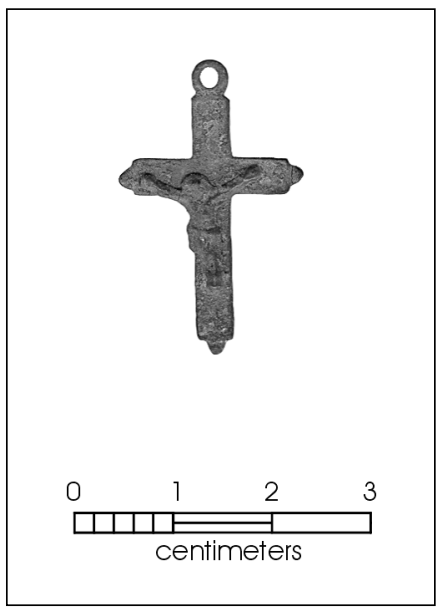

Figure 16. Copper crucifix.

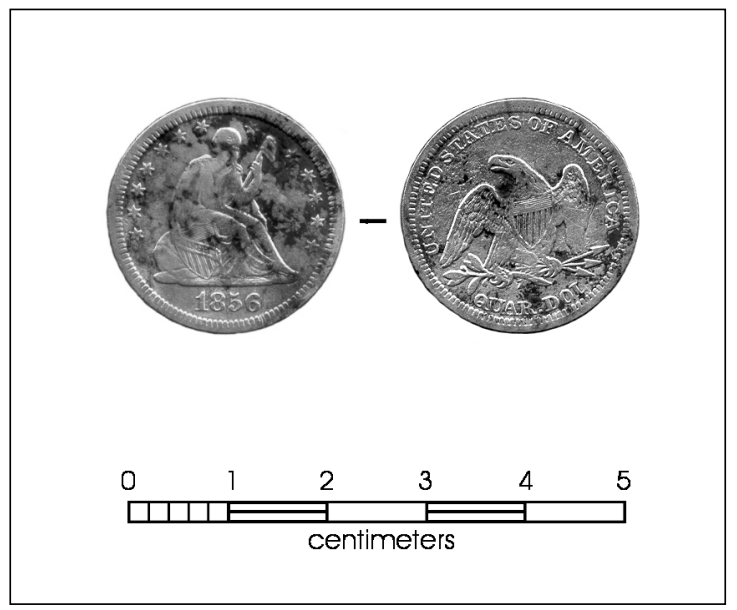

Figure 17. 1856 quarter dollar. 


\section{A rms and A mmunition}

Three rim-fired .22 short bullet casings were recovered. This is the most common ammunition made in the United States, and has been in use, essentially unchanged, since 1857 (Logan 1959:63). The fourth cartridge is a fragment of a center-fired brass .45 caliber rifle bullet. This cartridge was first made in the early 1870 s by the U.S. Army, and was for many years the official long arm ammunition for the services (Logan 1959:142). Only the badly damaged base of the copper alloy cartridge remains (Figure 18). It has been fired.

\section{Construction}

Most of the material in this artifact class is comprised of cut and wire nails and widow glass (Table 10). Other types of hardware, mortar, brick, and tile fragments are also included. Ninety-one percent $(\mathrm{n}=453)$ of the material in this class was recovered from Area 1. Not surprisingly, cut nails were most common in Area 1. A total of 150 window glass fragments was recovered, which ranged in thickness from $2 \mathrm{~mm}$ to 3 $\mathrm{mm}$. Only 10 window glass sherds were recovered outside of Area 1, all from Area 2.

Table 10. Construction-related Items

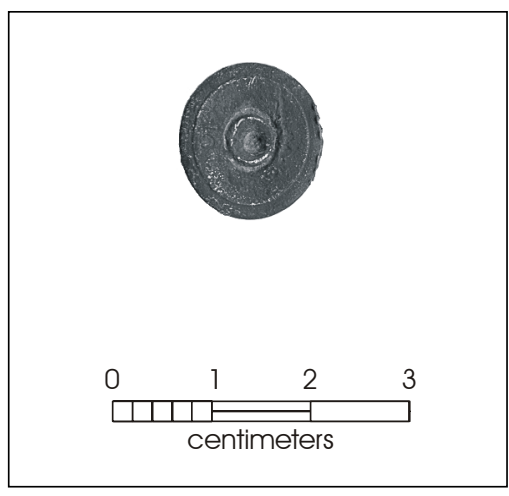

Figure 18. U.S. Army issue .45 caliber rifle cartridge fragment.

\begin{tabular}{|l|r|}
\hline \multicolumn{2}{|c|}{ Area 1 } \\
\hline Nails-Cut & 128 \\
\hline Nails-Wire & 79 \\
\hline Other hardware & 27 \\
\hline Window glass & 140 \\
\hline Brick & 27 \\
\hline Mortar & 50 \\
\hline Roofing material & 1 \\
\hline Asphalt & 1 \\
\hline & \\
\hline & \\
\hline \multicolumn{1}{|c|}{ Total } & 453 \\
\hline Nails-Cut 2 & 2 \\
\hline Nails-Wire & 11 \\
\hline Other hardware & 1 \\
\hline Window glass & 10 \\
\hline Brick & 5 \\
\hline Tile & 4 \\
\hline Mortar & 1 \\
\hline Asphalt & 3 \\
\hline Electrical wire & 1 \\
\hline Water pipe fragment & 1 \\
\hline & 39 \\
\hline & 2 \\
\hline Nails-Cut & \\
\hline & \\
\hline & \\
\hline
\end{tabular}




\section{Barn/ W orkshop}

Only 10 items that fall within this category were recovered (Table 11). The material consisted of a large leather strap buckle, machinery parts, and baling wire.

Table 11. Barn/Workshop Items

\begin{tabular}{|c|c|}
\hline \multicolumn{2}{|l|}{ Area 1} \\
\hline Strap hardware-buckle & 1 \\
\hline Gasket & 1 \\
\hline Wire & 2 \\
\hline Total & 4 \\
\hline \multicolumn{2}{|l|}{ Area 2} \\
\hline Plastic cog & 1 \\
\hline Metal parts & 4 \\
\hline Total & 5 \\
\hline \multicolumn{2}{|l|}{ Area 2} \\
\hline Wire & 1 \\
\hline Total & 1 \\
\hline
\end{tabular}

\section{M iscellaneous Items}

This category includes an assortment of mostly nondiagnostic artifacts including unidentified metal objects, unidentifiable metal scrap, fragments of plastic, rubber, tar, and a fossil (Table 12).

Table 12. Miscellaneous Items

\begin{tabular}{|c|c|}
\hline \multicolumn{2}{|l|}{ Area 1} \\
\hline Miscellaneous metal Items & 5 \\
\hline \multicolumn{2}{|l|}{ Unidentifable metal scrap } \\
\hline Iron & 319 \\
\hline Copper & 1 \\
\hline Tin & 2 \\
\hline Composition fragment & 1 \\
\hline Fossils & 1 \\
\hline Plastic & 5 \\
\hline Tar & 1 \\
\hline Unidentified material & 5 \\
\hline Total & 340 \\
\hline Area 2 & \\
\hline Unidentifable metal scrap & \\
\hline $\begin{array}{rr}\text { Iron } \\
\end{array}$ & 44 \\
\hline Plastic & 5 \\
\hline Rubber & 1 \\
\hline Tar & 2 \\
\hline Pumice (burned) & 1 \\
\hline Unidentified material & 2 \\
\hline Total & 55 \\
\hline Area 3 & \\
\hline Unidentifable metal scrap & \\
\hline Iron & 1 \\
\hline Plastic & 3 \\
\hline Total & 4 \\
\hline
\end{tabular}




\section{Lithics}

There were few indications of prehistoric occupation of the site recovered during this project (Table 13). Debitage was the largest category in this class $(n=43)$. Most of the debitage recovered in Area 1 was from ST2002-01/U2002-01 ( $\mathrm{n}=17$ ). Nine of the 17 shovel tests in Area 2 had at least one chert flake, while only one flake was recovered from Area 3. One untypeable projectile point was recovered from Area 1. It was broken during manufacture and possibly used as graver (Figure 19a). The only other stone tool recovered was a flake that has been trimmed along one edge (Figure 19b). There were no concentrations of lithic material evident within units, shovel tests, or levels.
Table 13. Lithics

\begin{tabular}{|l|r|}
\hline \multicolumn{2}{|c|}{ Area 1 } \\
\hline Dart point-untypeable & 1 \\
\hline Debitage & 25 \\
\hline Burned Rock Total & 29 \\
\hline \multicolumn{2}{|c|}{ Area 2 } \\
\hline \multicolumn{2}{|c|}{ Total } \\
\hline Arimmed flake 3 \\
\hline Debitage \\
\hline Burned Rock \\
\hline \multicolumn{2}{|c|}{ Total } \\
\hline \\
\hline Debitage \\
\hline
\end{tabular}

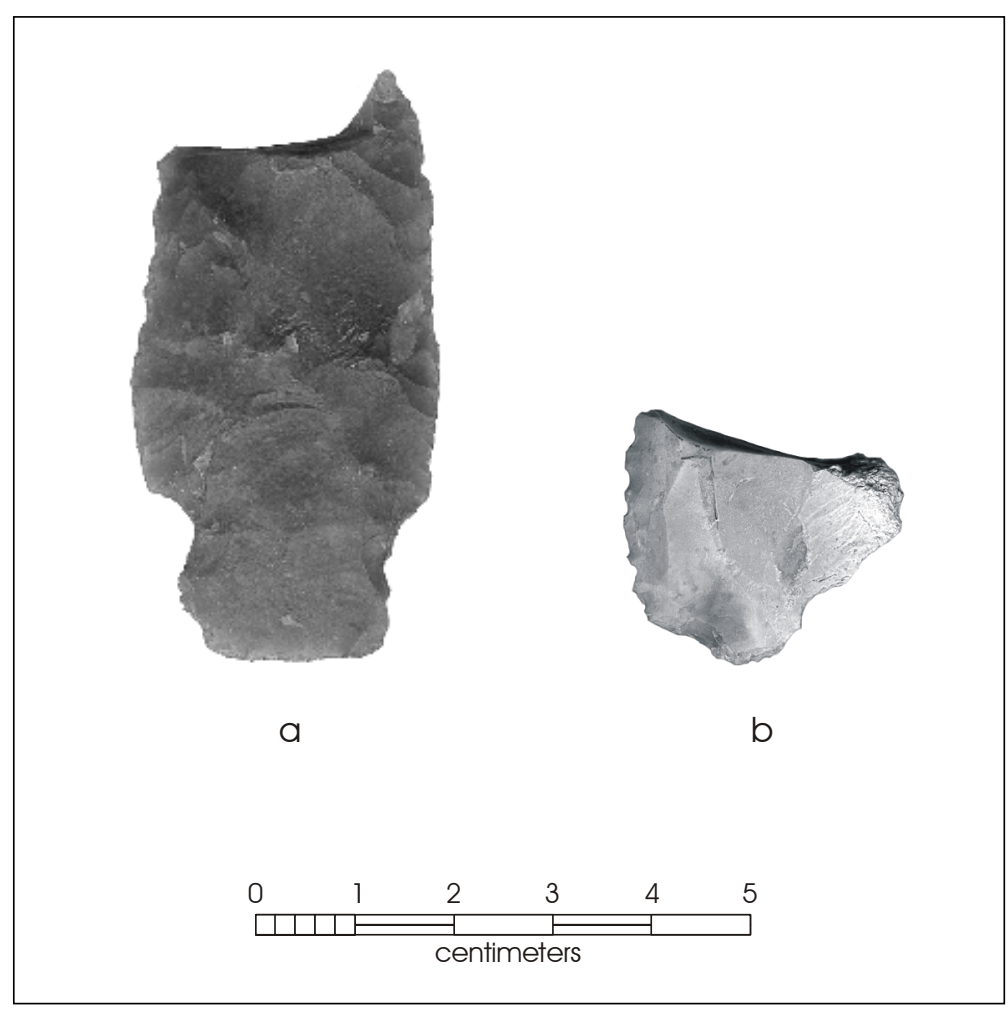

Figure 19. Stone tools: a) untypeable dart point; b) retouched flake. 


\section{Vertebrate Fauna}

A total of 184 vertebrate faunal remains, weighing 198.69 $\mathrm{g}$, was recovered during the project. The bone was recovered by screening through $0.64 \mathrm{~cm}(1 / 4$-inch $)$ screens. All bone was washed in tap water and air-dried. The bone was identified to the most specific taxon possible using the comparative collection at CAR, as well as several reference texts (Gilbert 1990; Gilbert et al. 1981; Hildebrand 1955; Olsen 1968).
Identifications were conservative, however, otherwise unidentifiable cow-sized bone that was sawed was tentatively identified as Bos taurus. All bone was weighed. Evidence of exposure to heat was noted on all bone. Element, portion of element, evidence of immaturity, butcher marks, and pathologies were noted on bone identified to the order taxonomic level. Bone identified to at least the order taxonomic level was bagged separately and included in the unit-level bags with unidentified bone. Table 14 is a list of the counts and weight of all bone by taxon.

Table 14. Vertebrate Fauna

\begin{tabular}{|c|c|c|c|}
\hline Taxa & Common Name & Count & Weight (g) \\
\hline Mammalia & Mammals & & \\
\hline cf. Bos taurus & Cattle & 8 & 58.89 \\
\hline Lepus californicus & Blacktailed jackrabbit & 3 & 3.19 \\
\hline Neotoma $\mathrm{sp}$. & Woodrats & 2 & 0.88 \\
\hline Pecari tajacu & Javelina, collared peccary & 1 & 0.34 \\
\hline Sigmodon hispidus & Cotton rat & 1 & 0.41 \\
\hline Sus scrofa & Domestic pig & 1 & 3.15 \\
\hline Sylvilagus sp. & Cottontail rabbit & 2 & 0.72 \\
\hline Artiodactyl & Deer, sheep, goats & 1 & 1.62 \\
\hline Bovinae & Cattle or bison & 1 & 9.47 \\
\hline Mammal--large & Deer, sheep-sized & 9 & 22.47 \\
\hline Mammal--very large & Cattle, bison, horse-sized & 21 & 44.58 \\
\hline \multirow[t]{2}{*}{ Mammal } & Size indeterminate & 69 & 28.79 \\
\hline & Total Mammals & 119 & 174.51 \\
\hline Aves & Birds & & \\
\hline Anas sp. & Ducks & 3 & 1.50 \\
\hline Gallus gallus & Chicken & 2 & 0.91 \\
\hline Meleagris gallopavo & Turkey & 2 & 3.07 \\
\hline Anatidae & Swans, ducks, geese & 1 & 2.43 \\
\hline \multirow[t]{2}{*}{ Aves } & Size indeterminate & 15 & 3.79 \\
\hline & Total Birds & 23 & 11.70 \\
\hline Reptilia & Reptiles & & \\
\hline Nerodia sp. & Water snakes & 37 & 11.35 \\
\hline \multirow[t]{2}{*}{ Emydidae } & Emydid turtles & 1 & 0.60 \\
\hline & Total Reptiles & 38 & 11.95 \\
\hline Osteichthyes & Boney Fishes & & \\
\hline Ictalurus sp. & Freshwater catfish & 2 & 0.36 \\
\hline \multirow[t]{3}{*}{ Osteichthyes } & Unidentified fish & 2 & 0.17 \\
\hline & Total Fishes & 4 & 0.53 \\
\hline & Overall Totals & 184 & 198.69 \\
\hline
\end{tabular}




\section{Chapter 6: Summary and Recommendations}

\section{Summary}

A total of 34 shovel tests and two test units were dug in three locations in San Pedro Springs Park during this investigation. The 1,779 artifacts recovered in these tests included those of modern, historic, and prehistoric origin. Monitoring, especially during trenching for the sprinkler system, allowed an examination of sediments close to ground level over a large area of the park.

This project allowed testing of three previously unexamined areas of the park. Area 1 was tested to bedrock. It is clear that in Area 1 there is a distinct deposit of artifacts resting just above the fractured limestone bedrock on the east, south, and southwestern areas around the Block House (Figure 5). This deposit is fairly dense and mixed, but is largely nineteenth-century in origin. There is no evidence of this deposit in the area north and northwest of the structure. The near absence of Colonial-period artifacts in Area 1 is consistent with the nature of the architecture of the Block House, and reaffirms the belief that the building was constructed in the 1850 s.

Area 2 tested sediments to $70-80 \mathrm{cmbs}$ when possible. Except in areas where old roadbeds were encountered, apparently undisturbed sediments were found at between 30 and $40 \mathrm{~cm}$ below ground surface.

Area 3 tested sediments to $70-75 \mathrm{cmbs}$ when possible. Most of Area 3 appeared to be fill to the depths tested. The results of the monitoring of tree planting near Area 3 confirmed the presence of large amounts of fill in this area.

\section{Recommendations}

Area 1 has been shown to have very shallow sediments. Artifacts found around the Block House are largely nineteenth-century and relate to the use of the vicinity as a public recreational area, and possibly as a residence in the mid-nineteenth century. Impacts in this area should be avoided or monitored by archaeologists when necessary.
Although road and parking construction near Area 2 has impacted sediments, there is still a possibility of intact cultural deposits. Future impacts in that area of the park should be monitored by a professional archaeologist. Impacts to the area between the new playground and the east-west walk, where a burned rock concentration is known to be buried, should be avoided.

The vicinity of Area 3 can now has been shown to be disturbed, at least to $50 \mathrm{~cm}$ in depth. The area where the trees were planted has been shown to be disturbed to about $60 \mathrm{~cm}$.

The sprinkler system trenches have shown areas that are disturbed by previous roads and parking lots, but perhaps most importantly, have identified areas all over the park that show no sign of disturbance. These areas are sometimes small, surrounded by disturbance (see Figure 12). Within them, however, lies the existing archaeological record of San Pedro Park. In order to protect this record, extreme care must be taken whenever proposed changes to the park may impact them. In order to assist future planners in avoiding or minimizing damage to important cultural deposits or features in the park, the maps produced in the final chapter of Meissner 2000 have been updated, and the accompanying recommendations for future activity in the park has been modified with the information gained during this project. The result is presented in Figure 20. The five "Zones" shown in Figure 20 are based on information from old maps, previous archaeological studies, and the current project. They are identified as follows:

Zone 1: Areas where cultural deposits or features are known to exist.

Zone 2: Areas where the nature of the cultural deposits is unknown.

Zone 3: Areas where sediments are known to be disturbed to at least 12 in. $(30 \mathrm{~cm})$.

Zone 4: Areas where sediments are known to be disturbed to at least a depth of $6 \mathrm{ft} .(183 \mathrm{~cm})$.

Zone 5: Areas where sediments are known to be disturbed to bedrock. 


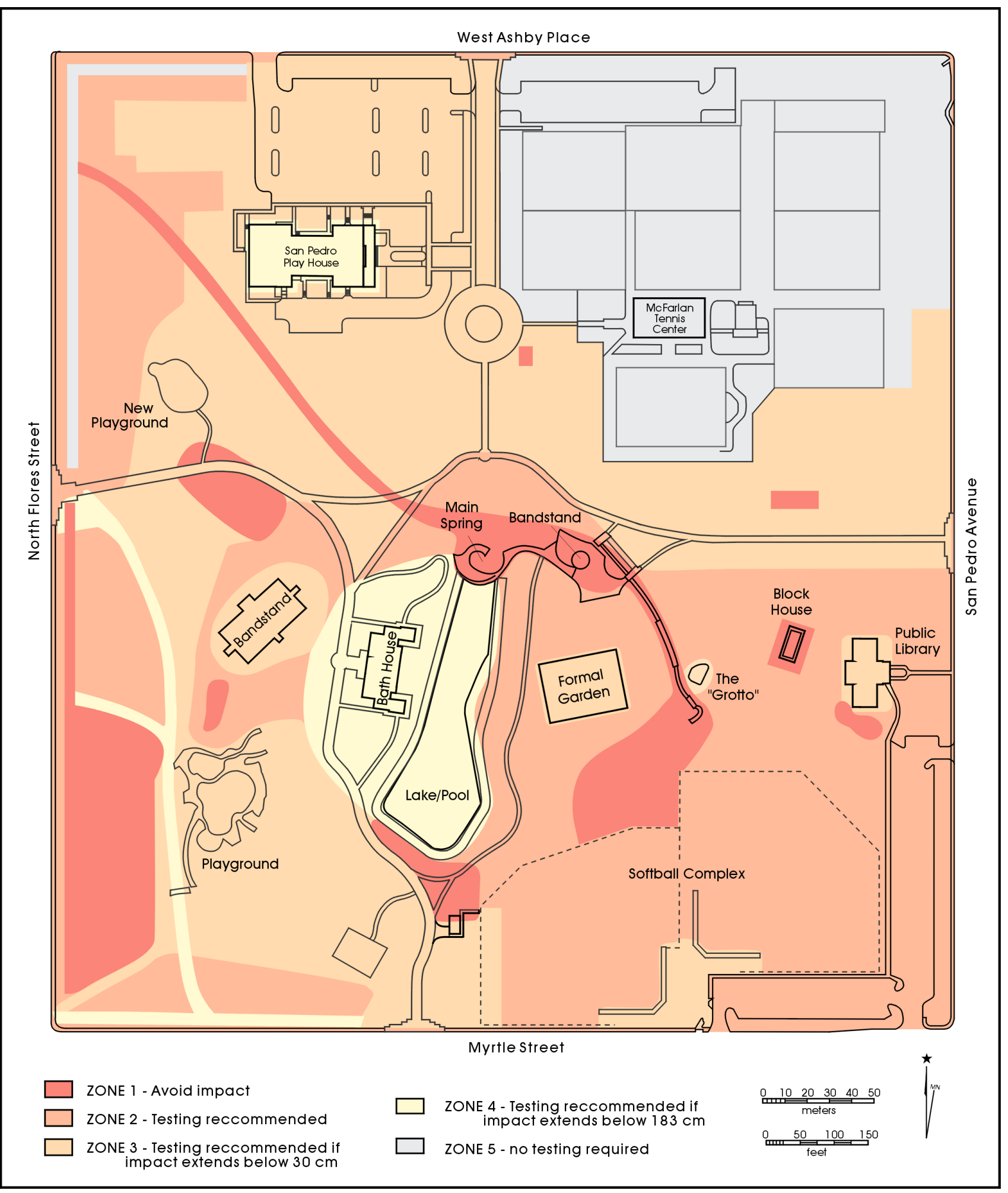

Figure 20. Impact zones within San Pedro Springs Park. 
Table 15 provides recommendations for each of the five zones noted in Figure 20, depending on the type and extent of the proposed impact.

It is important to note that while the monitoring of the trenching for the sprinkler system provided a glimpse of the subsurface of a large portion of the park, the trenches were not deep. We still know nothing about what is below the sediments impacted by those trenches. The majority of the disturbed areas noted in Figure 12 are the remains of roadbeds and parking lots that were recently removed. We can assume that the disturbance is not much deeper than the $30 \mathrm{~cm}$ or so that were observed during the trenching operation, and we do not know what is present below those disturbances.

The results of this project, combined with information from previous projects (Houk 1999; Meissner 2000), once more confirm the importance of the cultural resources in the park. Future impacts to the park should be considered carefully and an attempt should be made to restrict such impacts to areas known to have been previously disturbed.

Table 15. Recommendations for Various Levels of Impact within Identified Zones

\begin{tabular}{|c|c|c|c|c|c|}
\hline & \multicolumn{5}{|c|}{ Type of Impact } \\
\cline { 2 - 6 } & $\begin{array}{c}\text { Upper 4" } \\
\text { Zone }\end{array}$ & $\begin{array}{c}\text { Area }<3^{\prime}(90 \mathrm{~cm}) \\
\text { in diameter }\end{array}$ & $\begin{array}{c}\text { Impact depth } \\
\text { of } 4 " \text { to } 12^{\prime \prime} \\
(10 \text { to } 30 \mathrm{~cm})\end{array}$ & $\begin{array}{c}\text { Impact depth } \\
\text { of } 12^{\prime \prime} \text { to } 6{ }^{\prime} \\
(30 \text { to } 183 \mathrm{~cm})\end{array}$ & $\begin{array}{c}\text { Impact depth } \\
>66^{\prime}(183 \mathrm{~cm})\end{array}$ \\
\hline Zone 1 & None & Avoid & Avoid & Avoid & Avoid \\
\hline Zone 2 & None & Monitor & Testing & Testing & Testing \\
\hline Zone 3 & None & Monitor & Monitor & Testing & Testing \\
\hline Zone 4 & None & Monitor & None & Monitor & Testing \\
\hline Zone 5 & None & None & None & None & None \\
\hline
\end{tabular}




\section{References Cited}

Black, S. J.

1989 Central Texas Plateau Prairie. In From Gulf Coast to the Rio Grande: Human Adaptation in Central, South and Lower Pecos Texas by T. R. Hester, S. L. Black, D. G. Steele, B. W. Olive, A. A. Fox, K. J. Reinhard, and L. C. Bement, pp. 17-38. Research Series No. 33, Arkansas Archeological Survey, Fayetteville.

Brune, G.

1981 Springs of Texas, Vol. 1. Branch-Smith, Fort Worth.

Cox, I. W.

2000 San Pedro Park in the Nineteenth Century. In An Archeological Assessment of San Pedro Park, (41BX19) San Antonio, Texas, edited by B. A. Meissner, pp. 12-15. Archaeological Survey Report, No. 269. Center for Archaeological Research, The University of Texas at San Antonio.

Fox, A. A.

1978 Archaeological Investigations of Portions of the San Pedro and Alazán Acequias in San Antonio, Texas. Archaeological Survey Report, No. 49. Center for Archaeological Research, The University of Texas at San Antonio.

1979 A Survey of Archaeological, Architectural and Historical Sites on the San Antonio River, from Olmos Dam to South Alamo Street and on San Pedro Creek from San Pedro Park to Guadalupe Street. Archaeological Survey Report, No. 80. Center for Archaeological Research, The University of Texas at San Antonio.

Gilbert, B. M.

1990 Mammalian Osteology. Missouri Archaeological Society, Columbia.

Gilbert, B. M., L. D. Martin, and H. G. Savage

1981 Avian Osteology. B. Miles Gilbert, Publisher. Laramie, Wyoming.

Hildebrand, M.

1955 Skeletal Differences Between Deer, Sheep, and Goats. California Fish and Game 41:327-346.

Houk, B. A.

1999 Archeological Survey and Testing in San Pedro Park (41BX19), San Antonio, Texas. Archaeological Survey Report, No. 289. Center for Archaeological Research, The University of Texas at San Antonio.

Houk, B. A., D. L. Nickels, and B. A. Meissner

2000 The 1998 Investigations. In An Archeological Assessment of San Pedro Park, (41BX19) San Antonio, Texas, edited by B. A. Meissner, pp. 43-78. Archaeological Survey Report, No. 269. Center for Archaeological Research, The University of Texas at San Antonio.

Kendall, D. S.

2002 San Pedro Park. The Handbook of Texas Online. <http://www.tsha.utexas.edu/handbook/online/articles/view/ SS/gks12.html> Accessed October 9, 2002.

Logan, H. C.

1959 Cartridges: A Pictorial Digest of Small Arms Ammunition. Bonanza, New York. 
Meissner, B. A.

1997 Matters Public and Private: Items of Personal Use from the Alamodome Project. In Archaeology at the Alamodome: Investigations of a San Antonio Neighborhood in Transition, Vol. III, Artifact and Special Studies, edited by A. A. Fox, M. Renner, and R. J. Hard, pp. 165-208. Archaeological Survey Report No. 238. Center for Archaeological Research, The University of Texas at San Antonio.

Meissner, B. A. (editor)

2000 An Archeological Assessment of San Pedro Park, (41BX19) San Antonio, Texas. Archaeological Survey Report, No. 269. Center for Archaeological Research, The University of Texas at San Antonio.

Moulton, T. G.

2002 Kissing Cousins: A History of Insulator and Fruit Jar Manufacturers. Available online at $<$ http://www.insulators.com/ articles/fruitref.htm> Accessed October 20, 2002.

Munsey, C.

1970 The Illustrated Guide to Collecting Bottles. Hawthorn, New York.

Nickels, D. L., and I. W. Cox

1996 An Archaeological Assessment of the Alazán Acequia (41BX620) in the Five Points Area of San Antonio, Bexar County, Texas. Archaeological Survey Report, No. 253. Center for Archaeological Research, The University of Texas at San Antonio.

Olsen, S. J.

1968 Fish, Amphibian, and Reptile Remains from Archaeological Sites Part I: Southeastern and Southwestern United States. Peabody Museum, Cambridge.

Orchard, C. D., and T. N. Campbell

1954 Evidences of Early Man from the Vicinity of San Antonio, Texas. Texas Journal of Science 6(4):454-465.

Pool, J. C.

1987 Fanthorp Inn: A Study of Nineteenth and Twentieth Century Buttons. In Archeological Excavations at Fanthorp Inn State Historic Site (41GM79), Grimes County, Texas, Spring and Fall 1982, by J. D. Ing and J. Hart, pp. 277290. Texas Parks and Wildlife Department, Historic Sites and Restoration Branch, Austin.

San Antonio Parks and Recreation Department

2002 San Pedro Springs Park, 1315 San Pedro, A History. <http://www.ci.sat.tx.us/sapar/sanpedrohis.asp > Accessed October 8, 2002.

Schuetz, M. K.

1969 The History and Archaeology of Mission San Juan Capistrano, San Antonio, Texas. Volume II: Description of the Artifacts and Ethno-History of the Coahuiltecan Indians. Archaeological Program Report No. 11. State Building Commission, Austin, Texas.

Stelle, L. J.

2001 An Archaeological Guide to Historic Artifacts of the Upper Sangamon Basin. Center For Social Research, Parkland College. <http://virtual.parkland.cc.il.us/lstelle1/len/archguide/documents/arcguide.htm> Accessed October 29, 2002. 
Taylor, F. B., R. B. Hailey, and D. L. Richmond

1991 Soil Survey of Bexar County, Texas. United States Department of Agriculture, Soil Conservation Service, Washington, D.C.

Toulouse, J. H.

1971 Bottle Makers and Their Marks. Thomas Nelson, New York.

Yakubik, J.

1990 Ceramic Use in Late-Eighteenth-Century and Early-Nineteenth-Century Southeastern Louisiana. Unpublished Ph.D. Dissertation, Tulane University.

Zapata, J. E.

1997 Alamodome and Abroad: A Composite Inquiry on Toy Marbles. In Archaeology at the Alamodome: Investigations of a San Antonio Neighborhood in Transition, Vol. III, Artifact and Special Studies, edited by A. A. Fox, M. Renner, and R. J. Hard, pp. 100-119. Archaeological Survey Report, No. 238. Center for Archaeological Research, The University of Texas at San Antonio. 